\title{
IDuke $\mathfrak{Z}$ aw $\mathfrak{J}$ oumal
}

VOLUME 1971

JUNE

NUMBer 2

\section{THE HEARING EXAMINER LOAN PROGRAM}

\section{ANTONIN SCALIA*}

The Attorney General's Committee on Administrative Procedure, whose report was the foundation of the Administrative Procedure Act,' characterized the selection and retention of qualified hearing examiners as "the heart of formal administrative adjudication."2 Another commentator has observed that the hearing examiner provisions of the APA "probably constitute the most important modifications in the adjudication process brought about by the Act."3 The present article deals with past experience and future prospects under one of these provisions which has received less attention than its inherent interest and long-range implications might warrant.

In its entirety, the "hearing examiner" section of the APA reads as follows:

Sec. 11. Subject to the civil-service and other laws to the extent not inconsistent with this Act, there shall be appointed by and for each agency as many qualified and competent examiners as may be necessary for proceedings pursuant to sections 7 and 8 , who shall be assigned to cases in rotation so far as practicable and shall perform no duties inconsistent with their duties and responsibilities as examiners. Examiners shall be removable by the agency in which they are employed only for good cause established and determined by the Civil Service Commission . . . after opportunity for hearing and upon the record thereof. Examiners shall receive compensation prescribed by the Commission independently of agency recommendations or ratings and in accordance with the Classification Act of 1923 . . . Agencies occasionally or temporarily insufficiently staffed may utilize examiners selected by the

* Professor of Law, University of Virginia Law School. This article is based substantially upon a study conducted in the Summer of 1970 for the United States Civil Service Commission. I wish to express my appreciation to Wilson M. Matthews, Esquire, then Director of the Office of Hearing Examiners, and to Charles J. Dullea, Esquire, the present Director, for their invaluable assistance.

1. Act of June 11, 1946, ch. 324, 60 Stat. 237, codified in scattered sections of 5 U.S.C. (Supp. V, 1970) [hereinafter cited as APA].

2. ReP. Att'y Gen. Comm. Ad. Proc. 46 (1941) [hereinafter cited as ATt'y Gen. ReP.].

3. M. Bernstein, Regulating Business by Independent Commission 196 (1955). 
Commission from and with the consent of other agencies. For the purposes of this section, the Commission is authorized to make investigations, require reports by agencies, issue reports, including an annual report to the Congress, promulgate rules, appoint such advisory committees as may be deemed necessary, recommend legislation, subpoena witnesses or records, and pay witness fees as established for the United States courts.'

The specific concern of this study is the implementation of that sentence of the original section 11 italicized above. As recodified in section 3344 of Title 5 of the United States Code, ${ }^{5}$ the sentence now reads as follows:

An agency as defined by section 551 of this title which occasionally or temporarily is insufficiently staffed with hearing examiners appointed under section 3105 of this title may use hearing examiners selected by the Civil Service Commission from and with the consent of other agencies. ${ }^{\circ}$

Responsibility for implementing the various provisions of section 11 of the APA, including the loan provision, was until 1954 distributed among various departments of the Civil Service Commission (referred to in this article as the Commission), with the Executive Director providing coordination and direction. In partial compliance with a recommendation made by the 1953 President's Conference on Administrative Procedure, ${ }^{7}$ the Commission in 1954 established a separate job classification to coordinate the hearing examiner program, with the title of "Administrative Officer." Finally, in 1962, it created the current Office of Hearing Examiners under the supervision of its own Director, who reports through the Executive Director directly to the Commission. This Office is charged not merely with the coordination but with the direction of the entire hearing examiner program. Its Director has been assigned "total responsibility for planning, operating, and directing a nationwide program for the employment and compensation of Hearing Examiners," and "complete authority to act in all areas except those matters specifically reserved to the full Commission."

4. Act of June 11, 1946, ch. 324, $\S 11,60$ Stat. 244 (emphasis added).

5. 5 U.S.C. $\S 3344$ (Supp. V, 1970). The 1966 recodification of Title 5, Act of Sept. 6, 1966, Pub. L. No. 89-544, 80 Stat. 378 , separated the various provisions of section 11 of the APA and scattered them in various sections, with some necessary alterations in wording although not in substance.

6. 5 U.S.C. $\S 3344$ (Supp. V, 1970).

7. The Conference had recommended that a Burcau of Hearing Examiner Administration be established within the Commission. RePORT OF THE CONFERENCE ON ADMinistrative Procedure 9 (1953).

8. Civil Service Commission Position Description-Director, Office of Hearing Examiners, 
In operation, the Ioan provision of section I I has developed from an occasional convenience into a regular feature of the hearing examiner system. In the six and one-half years from June 11, 1947, the date the examiner-selection provisions of section 1 I became effective, to January 1954, the Commission authorized a total of only 9 Ioans. In Fiscal Year 1955 alone it authorized 10; in Fiscal 1959, 20; and in FiscaI 1967, 48. In Fiscal 1969, the annual rate increased to 96 , a peak which was almost matched in Fiscal 1970 when 86 loans were made. ${ }^{9}$ The extent of the loan business is apparent from the following list of agencies to which section 11 loans have been made: ${ }^{10}$

\author{
Atomic Energy Commission \\ * Board of Parole, Department of Justice \\ * Bureau of Commercial Fisheries \\ Bureau of the Mint \\ Bureau of Narcotics \& Dangerous Drugs, \\ Department of Justice \\ Civil Service Commission \\ Comptroller of the Currency \\ Department of Commerce \\ Department of Housing \& Urban \\ Development \\ *Federal Deposit Insurance Corporation
}

\author{
Federal Highway Administration, \\ Department of Transportation \\ * Federal Home Loan Bank Board \\ Federal Power Commission \\ * Federal Reserve Board \\ Food and Drug Administration, HEW \\ Internal Security Division, \\ Department of Justice \\ Japanese Claims Section, \\ Department of Justice \\ * National Labor Relations Board \\ National Transportation Safety \\ Board, Department of Trans- \\ portation
}

at 1 (1962). The full text of this Position Description is eontained in Attachment 2 to the REPORT of Advisory Committee for Hearing Examiners to United States Civil Service COMMISSIONERS (1963). The Report contains a description of the history of administration of the Hearing Examiner Program. See id. at 15.

There has in fact been much more continuity to the administration of the hearing examiner program than the organizational history described in the text might suggest. From the date of passage of the APA until April, 1971, with the exception of a brief period during 1961, initial responsibility for coordination and direction of all of the Commission's functions pertaining to hearing examiners rested with a single individual, Wilson $M$. Matthews. He was appointed Administrative Officer in eharge of the program when that position was established in 1954 and was the Director of the Office of Hearing Examiners from its creation in 1962 until his retirement in April, 1971.

9. These figures on annual loans are the Commission's own computations, made at various times and for various internal purposes. It is likely that the basis of computation was not consistent in one respect. The 1969 and 1970 figures include as separate loans those extensions which pertain to loans made during the preceding fiscal year; the figures for the early years-at least until 1954-do not appear to do so; and the basis of computation for the intervening years is impossible to determine. Moreover, even if extensions were counted for purposes of the earlier computations, some distortion would still exist by reason of the fact that the permissible duration of the original loan has varied through the years, thereby creating an irrational variation in the number of extensions. Since, however, the extensions constitute a relatively small proportion of the total figure, even in the most recent years, and since many extensions are for the purpose of hearing entirely new cases, the figures given in the text should provide at least a rough representation of the constant and accelerating growth of loan business.

10. An asterisk indicates tbat the borrowings have been frequent. 
Office of Director of Practice, Bureau of Internal Revenue, Treasury Department

Office of Economic Opportunity

* Office of Education, HEW

Office of the Secretary,

Department of Interior

* Office of the Secretary, HEW

Office of Special Assistant to the President

Oil Import Administration, Department of Interior
Patent Office

Post Office Department

Securities and Exchange Commission

Small Business Administration

Social and Rehabilitation

Service, HEW

Subversive Activities Control Board

Veterans' Education Appeals Board

The agencies which have loaned examiners include the following:"

Alcohol and Tobacco Tax Division,

Bureau of Internal Revenue,

Treasury Department

Atomic Energy Commission

Bureau of Commercial Fisheries

Bureau of Land Management

Civil Aeronautics Board

*Civil Service Commission

Department of Agriculture

Federal Communications Commission

Federal Maritime Commission

Federal Power Commission

Federal Railroad Administration
* Federal Trade Commission Interstate Commerce Commission Maritime Administration, Department of Commerce National Labor Relations Board Office of Alien Property, Department of Justice Post Office Department Securities and Exchange Commission * Small Business Administration *Social Security Administration, HEW Subversive Activities Control Board

One may properly conclude from the foregoing statistics that the hearing examiner loan program has grown to become an accepted and important feature of the administrative system. It is a feature, however, whose operation and effects have received no systematic study, neither in reports to the Commission itself nor in the mass of Iaw review articles and other published material dealing with hearing examiners in general. References to the loan program do, indeed, abound; they are generally made, however, not for the purpose of increasing the available knowledge concerning the characteristics and effects of the program, but for the purpose of basing further conclusions upon what are presumed to be those characteristics and effects. Thus, despite the absence of any systematic evaluation of the performance of borrowed examiners, the Ioan program has been cited

Il. An asterisk indicates that the loans have been frequent. 
as proof that selective certification is not necessary,,$^{12}$ and indeed that all hearing examiners may successfully operate from a common "pool," neither employed by, nor specializing in the work of, any particular agency. ${ }^{13}$ Such conclusions may or may not be correct; but certainly the loan program can shed no light upon them until more is known about the effectiveness of the loan program itself.

The present study, then, will seek to satisfy the need for more concrete information concerning a program which has considerable importance both in its own right and as an experimental divergence from the usual procedures for providing examiners to handle agency business.

\section{The Scope of the Loan Provision of the APA}

This article is concerned only with those loans or "details" of hearing examiners which fall under the supervision of the Civil Service Commission by virtue of section 11 of the APA. The question initially arises whether this category includes all loans of hearing examiner personnel. The Commission has taken the position that it does not, but rather is limited to those loans made for the purpose of conducting hearings as required under sections 4 and 5 of the APA. ${ }^{14}$ More specifically, the Commission has maintained that the detail of an examiner to another agency for a purpose other than the conducting of an APA hearing may be made by the employing agency itself, without even the need for Commission approval.

This interpretation of the loan provision of the APA is not inevitable, but it seems correct. Two positions may be taken in opposition to it. First, one may argue that the loan provision, with its requirement of Commission selection, applies to all loans of hearing examiners, not just those for the purpose of holding APA hearings. Such an interpretation, however, seems to run counter to that portion of the original loan provision ${ }^{15}$ which limits its applicability to "agencies occasionally or temporarily insufficiently staffed." This seems reasonably to refer to insufficient staffing with respect to that

12. See notes $72-74$ infra.

13. See text accompanying notes 102, 107-09 infra.

14. 5 U.S.C. $\S \S 553-54$ (Supp. V, 1970). Section 7 of the APA requires that such hearings be presided over by hearing examiners appointed under section 11 , unless the agency or one or more members of the body which comprises the agency preside. 5 U.S.C. $\S 556(\mathrm{~b})$ (Supp. V, 1970).

15. See the italicized portion of section 11 appearing in text at note 4 supra. 
work which only hearing examiners can perform, so that the "utilization" referred to later in the sentence must similarly be interpreted to apply only to utilization for APA hearing purposes. This point was strengthened by the re-wording of the loan provision in connection with the 1966 recodification; section 11 now refers not merely to agencies "insufficiently staffed" but to agencies "insufficiently staffed with hearing examiners appointed under section 3105."16 The brief discussion of the loan provision found in the legislative history of the APA appears to assume that it applies only to loans for APA hearing purposes. ${ }^{17}$ Such an assumption is even more evident in the Final Report of the Attorney General's Committee on Administrative Procedure, whose Recommendation 1(d) with respect to Formal Adjudication was the original source of the loan provision of the APA. ${ }^{18}$

The second position in opposition to the Commission's view acknowledges that section 11 only has explicit reference to details for the purpose of holding APA hearings. It concludes from this, however, not that other loans do not require Commission supervision but that other loans are not permitted. That is, according to this view the provision of specific procedures for only one type of loan is an indication that only that type is allowable. Representing an application of the ancient canon of construction "inclusio unius, exclusio alterius," such an interpretation is textually tenable. But it makes little practical sense in view of other rules governing the use of examiners. As will be discussed below, there is little doubt that a hearing examiner may be used for non-APA purposes within his own agency, where the risk of compromising his impartiality or lessening his stature is much greater than it is on loan. Thus, to interpret section 11 as proscribing loans for non-APA purposes is to attribute to the legislature the intent to strain out the gnat after having swallowed the camel.

Of course there are some restrictions upon the purposes for which these non-APA details can be made. All loans must comply with that provision of section 11 which forbids assignment of hearing examiners, even within their own agency, to duties "inconsistent with

16. 5 U.S.C. $\$ 3344$ (Supp. V, 1970) (emphasis added).

17. See H.R. REP. No. 1980, 79th Cong., 2d Sess. 46-47 (1946), reprinted in Administrative Procedure Act, Legislative History, S. Doc. No. 248, 79th Cong., 2d Sess. 281 (1946) [hereinafter cited as APA: Legislative History].

18. See AtT'y Gen. ReP. 49. 
their duties and responsibilities as hearing examiners." 19 The precise meaning of "inconsistent" has not yet been definitively established and seems likely to be a source of controversy in the future. It clearly forbids assignment of an examiner to prosecutory duties within his agency; but in the past, hearing examiners at both the Federal Communications Commission and the Civil Service Commission have asserted that it prevents the imposition of any non-hearing duties, including participation on boards of review. This assertion was rejected by the Commission ${ }^{20}$-rightly, it seems, in view of the legislative history of section $\mathrm{II}$. As originally introduced in both the House and the Senate, it provided that hearing examiners "shall perform no other duties" than the hearing and deciding of cases. ${ }^{21}$ If the language of the bill as finally enacted-"no duties inconsistent with their duties and responsibilities as hearing examiners"-is construed to permit the assignment of no additional duties beyond the hearing and deciding of non-APA cases, the deliberate change in wording will have been deprived of any effect. This is not to say that only participation in prosecutory matters would be "inconsistent" within the meaning of the Act; certainly there are other assignments which come within the prohibition, not because they compromise the examiner's impartiality but because they demean his status. It was partly on this ground that the Committee on Hearing Examiners of the American Bar Association Section on Administrative Law successfully opposed the assignment of hearing examiners at the United States Coast Guard to serve as assistant legal assistance officers. ${ }^{22}$ But this interpretation still leaves a wide range of

19. 5 U.S.C. $\S 3105$ (Supp. V, 1970).

20. Interview with Wilson M. Matthews, Director, Office of Hearing Examiners, U.S. Civil Service Commission, Washington, D.C., Aug. 11, 1970.

in recent months, examiners of another agency, the Interstate Commerce Commission, have taken a position almost polar to that which their confreres earlier adopted. They claim the right to represent agency employees in administrative appeals before the ICC. Not only do they seee nothing in section 11 which prohibits this, but they assert that attempted prohibition would vinlate the Commission's regulations which permit an employee presenting an appeal "to be accompanied, represented and advised by a representative of his own choosing," 5 C.F.R. $\S 771.201(a)(2)(1970)$, and assure that representative, if he is another agency employee, "a reasonable amount of official time" to present the appeal. Id. $\S \S 771.201(\mathrm{~b})(2), 771.206$. The Office of Hearing Examiners has maintained that acting in an adverse capacity against the agency is "inconsistent" with the duties and responsibilities of the hearing examiners under section 11 .

21. This provision was contained in section 7 (a) of the bill introduced by Senator McCarran, S. 7, 79th Cong., Ist Sess. (1946). See A PA: Legislative History 11, 158.

22. Interview with John T. Miller, Jr., former Chairman, Committee on Hearing 
permissible assignment within the examiner's own agency-and permissible loan-beyond the hearing and deciding of cases.

One more limitation upon non-APA loans - and again one which is applicable also to intra-agency assignment -is contained in the Civil Service Commission's regulations. Absent a Commission finding that waiver of the restriction is in the public interest, no examiner may be assigned without Commission approval to perform "duties that are not duties of a hearing examiner" (that is, non-APA work) unless the assignment is to last no longer than 120 days and the hearing examiner has not had an aggregate of more than 120 days of such assignments within the preceding 12 months. ${ }^{23}$

As limited by the above-described restrictions, non-APA examiner loans arranged between the agencies themselves are not uncommon. The most frequent are for the purpose of holding hearings concerning personnel grievance matters such as suspensions and removals. At least some, however, have been for non-hearing purposes: for example, the numerous borrowings which the Civil Service Commission itself has made in order to meet its responsibilities for the provision of federal examiners under section 6 of the Voting Rights Act of $1965 .{ }^{24}$

One extraordinary series of loans represents a departure from the Commission's policy of refusing to arrange loans for non-APA purposes - though not a departure from its position that Commission arrangement in such cases is not required. Under the LaborManagement Relations Act, the National Labor Relations Board is empowered to issue orders requiring persons to cease and desist from unfair labor practices defined in the Act. ${ }^{25}$ The resulting orders, however, are not self-executing, but require enforcement through judicial decrees and, in the event of further infraction, through civil contempt proceedings for violation of the judicial decrees. ${ }^{26}$ Although these contempt proceedings must ordinarily be brought in United States courts of appeals, they frequently involve factual disputes which require the taking of evidence-a function which appellate

Examiners, ABA Section on Administrative Law, Washington, D.C.. Aug. 12, 1970. See 4 ABA Ad. Law Section, Annual Rep. of Comms. 10 (1967) (Hcaring Examiners Comm. 1966-67).

23. See 5 C.F.R. $\S 930.209$ (1970).

24. 42 U.S.C. $§ 1973 d$ (Supp. V, 1970).

25. Labor-Management Relations Act (Taft-Hartley Act) $\S 10(c), 29$ U.S.C. $\$ 160(c)$ (1964).

26. Id. $\S 10(\mathrm{e}), 29$ U.S.C. $\S 160(\mathrm{e})$ (1964). 
courts are neither equipped nor inclined to perform. Hence, the matter is normally referred to a court-appointed Special Master who conducts a hearing and makes findings of fact and conclusions of law. ${ }^{27}$ These Special Masters are usually active United States district judges or retired United States district or court of appeals judges, but the press of other business frequently renders such individuals unavailable. The appointment of a private attorney, which is permissible, has several disadvantages: A practitioner's impartiality in labor matters is less apparent; he is likely to be inexperienced in the conduct of hearings; the more successful a lawyer he is, the less time he can find to devote to the case; and the court must find funds to compensate him adequately - which ordinarily means that a fairly substantial bill will be assessed against one or both of the parties. ${ }^{28}$ Two courts of appeals, the First and the Fifth Circuits, saw a solution to the difficulty in the use of federal hearing examiners. There were, however, several obstacles to be overcome. Use of the NLRB's own examiners would have appeared improper, since the agency itself is ordinarily the complaining party; moreover, the NLRB examiner staff is not notably short of work. The direct borrowing of an examiner by the NLRB for re-loan to the court would have avoided these problems, but would have given the Board an unseemly amount of discretion in the selection of the person to adjudge its own case. The ideal solution which was devised might be termed the "simulated section 11 loan." Mimicking its section 11 procedures, which are not

27. Although the Federal Rules of Appellate Procedure make no provision for the appointment of masters, the power is inherent. See Kaufman. Masters in the Federal Courts: Rule 53. 58 Colum. L. Rev. 452, 462 (1958). Rule 53 of the Federal Rules of Civil Procedure contains detailed provisions concerning masters. Although this rule is of course applicable only to United States district courts, it is often used by analogy to govern the use of masters in courts of appeals. See 2B W. Barron \& A. Holtzoff, Federal Practice and Procedure § 1161 , at 577 (C. Wright ed. 1961); 5 J. Moore, Federal Practice if 19 53.02[2], 53.02[7] (1969). See, e.g., NLR B v. Teamsters Local 282, 428 F.2d 994, 1006 (2d Cir. 1970).

28. Cf. FED. R. Civ. P. 53(a). The importance of this last-mentioned factor of compensation is exemplified by the following excerpt from a letter addressed to the Office of Hearing Examiners by the Chief Judge of one United States court of appeals, seeking the appointment of an examiner as Special Master in an NLRB contempt proceeding:

[A]t this time of year our district court is very busy and I hesitate to appoint a district judge as master, and I doubt whether the respondent is in a position to compensate a private attorney in that position. Accordingly, I would like to call upon you, if that is appropriate, and to ask you to submit a name for the court to designate.

Letter from Chief Judge Bailey Aldrich. United States Court of Appeals for the First Circuit, to Office of Hearing Examiners. U.S. Civil Serv. Comm'n (undated letter on file at U.S. Civil Serv. Comm'n, Washington, D.C.). 
genuinely applicable since the contemplated hearing is not "required by the APA," the Commission arranges a loan to the NLRB for the purpose of re-loan to the courts. Acting not under the APA, but presumably under its more general authority and responsibility to meet the personnel needs of federal agencies, the Commission plays the role of the indispensable broker, enabling the NLRB to obtain and to provide an examiner untainted by NLRB selection.

The Office of Hearing Examiners does not rigidly segregate these NLRB loans from its section 11 loan business; to the contrary, it apparently attempts to make them resemble section 11 loans as much as possible. Their uniqueness is apparent, however, from several procedures preliminary to those which accompany the normal loan. The initial notice received by the Commission is not the loan request from the agency itself, but an inquiry from the clerk of court. In reply the Commission supplies the names and brief biographies of two or three examiners who are available. ${ }^{29}$ When the court has informed the Commission of its selection from among this group, the subsequent procedures are arranged to look like an ordinary section 11 loan: The NLRB makes written request for appointment of an examiner "under the provisions of Civil Service Regulation 930.213" (the regulation implementing the loan provision of section 11), and the Commission obligingly appoints the very examiner selected by the court. Extensions are arranged directly between the NLRB and the Commission, with no further intervention by the court.

From all indications, the simulated section 11 loan has been a most successful device for all parties concerned. The NLRB and the private litigants have had the benefit of expedition in the arrangement of the hearing, and of economy, ${ }^{30}$ undoubted impartiality, and unusual skill ${ }^{31}$ in the conduct of the proceedings and the determination

29. This is in sharp contrast to the normal section 11 procedures, under which a single examiner is selected and appointed by the Commission. See p. 335 of text infra.

30. The examiner's services are not necessarily provided by the NLRB free of charge to the private litigant. The apportioning of the cost of the examiner lies, of course, within the discretion of the court, $c f$. FED. R. CIV. P. 53(a), and it is usually divided between the parties. Such division is achieved in the cases under discussion by requiring the private party to reimburse the NLRB for one-half of the Special Master's compensation and expenses. See, e.g., NLRB v. Alamo Express, 395 F.2d 481, 484 (5th Cir. 1968). Since, however, this compensation consists mercly of a ratable portion of the examiner's annual salary, and takes no account of overhead costs, it is significantly less than would be required to retain a private attorney of the required ability. One suspects, however, that the major attraction of examiners is not the economy of their skilled services, but their impartiality and ready availability for lengthy periods of time.

31. For a case adopting the recommended findings of fact and conclusions of law of a 
of the disputed matters. The borrowing courts have had the benefit of experienced professional services of which they were in dire need and which were in temporary oversupply elsewhere within the same federal government. And the examiners themselves have had the benefit of assignments which not only added variety to their regular routine but increased their own sense of pride and professionalism. The procedure does, of course, present some danger of burdening the Commission and the examiner corps with too much of a good thing. But so far only the First and Fifth Circuits have sought to make use of the simulated section 11 loan, and at least for the time being the Commission seems able to meet their needs. If and when the number of requests becomes excessive, the loans can simply be refused. No agency need loan an examiner, even under section 11; and in a non-section 11 situation, the Commission itself has no obligation even to try to arrange a loan. 1t seems best, therefore, to leave this problem of possible over-demand to the discretion of the Office of Hearing Examiners, to make or refuse NLRB loans as conditions dictate; for although the Office's records and procedures conceal the nonstatutory character of this business, there does exist an awareness that it is, in a sense, superogatory and subsidiary to the main task of the loan program.

One other possible limitation upon the scope of the section 11 loan program must be mentioned briefly, if only to reject it. On one occasion, a member of the legal staff of a borrowing agency suggested to the Office of Hearing Examiners that the loan provision of the APA may not be used by agencies with no hearing examiners of their own. His position was based upon an exceedingly narrow interpretation of the phrase which section 11 uses to describe those agencies which may borrow examiners - "[a]gencies occasionally or temporarily insufficiently staffed ...." 32 An agency which has no staff of examiners, the argument runs, cannot be considered merely "occasionally or temporarily insufficiently staffed." That such an interpretation is possible under common usage is apparent from the following statement: "The provision permitting agencies to borrow examiners is intended to permit those who do not have full-time examiners to borrow them as needed as well as to aid those agencies

borrowed examiner in toto, and singling out his "thorough report" for special praise, see NLRB v. Southwire Co., 429 F.2d 1050, 1058 (5th Cir. 1970).

32. The current codification of section 11 reads "an agency ... . which occasionally or temporarily is insufficiently staffed with hearing examiners . . . " 5 U.S.C. $§ 3344$ (Supp. V, 1970). 
which may become temporarily or occasionally insufficiently staffed." 33 But since that statement is contained in the legislative history of section 11 itself, it demonstrates, paradoxically enough, that its own use of the phrase "occasionally or temporarily insufficiently staffed" was not the use intended by the APA. And there is, of course, another acceptable meaning of the phrase. An agency may be said to be "sufficiently staffed" with hearing examiners when it has none at all, but also has no APA business for which they are required; and when such an agency acquires an APA case, it may be said to become "temporarily" insufficiently staffed.

As noted above, almost all of the section 11 loans authorized since the enactment of the APA have been to agencies with no staffs of their own. Even if the legislative history were ambivalent, then, there would be strong reason to reject a narrow interpretation of the critical phrase. Surely that reading should be preferred which leaves some substantial function for section 11 to perform. But as a matter of fact, the legislative history is far from ambivalent. In addition to the sentence from the House committee report quoted in the preceding paragraph, the Report of the Attorney General's Committee on Administrative Procedure, wherein the loan provision originated, clearly indicates that borrowings by "unstaffed" agencies were envisioned. ${ }^{34}$

\section{Procedure FOR LOAN}

A section implementing the loan provision of the APA was included in the Commission's proposals for its first permanent Hearing Examiner Regulations. ${ }^{35}$ lt read as follows:

$\$ 34.12$ Utilization of examiners of other agencies. (a) At the request of agencies occasionally or temporarily insufficiently staffed, the Commission will arrange, if possible, for the temporary utilization by those agencies of the services of hearing examiners of other agencies.

(b) Agencies, by agreement between themselves, may arrange for the

33. Report OF the House COMm. ON THE JUdiciary, H.R. Rep. No. 1980, 79th Cong., $2 \mathrm{~d}$ Sess. 47 (1946) (emphasis added), reprinted in A PA: Legislative History 281.

34. See the excerpt from the Report quoted in text following note 53 infra.

35. Because of "conflicting interests [which] could not be reconciled," Macy, The APA and the Hearing Examiner: Products of a Viable Political Society, 27 FED. B.J. 351, 366 (1967), the regulations were not ready in time to meet the June 11,1947 , deadline established by section 12 of the APA for application of the examiner-selection provisions of section 11. The permanent regulations were therefore preceded by a temporary regulation adopted on May 29, 1947, which permitted conditional reappointment, on June 11, 1947, of incumbents of hearing examiner positions. 12 Fed. Reg. 3507 (1947). 
temporary utilization by one agency of a hearing examiner or hearing examiners of another agency. Such agreements must have the prior approval of the Commission before being put into effect..$^{36}$

Doubtless because of the presence of many more controversial issues in the proposed regulations (notably, the provisions for selection and removal of examiners), section 34.12 drew little comment, both in the public hearing held on July 9, 1947, and in written submissions to the Commission. A representative of the Securities and Exchange Commission urged that no Commission approval should be required for a borrowing and that a mere report to the Commission should suffice. ${ }^{37}$ At a meeting of the Commission and its Advisory Committee on Hearing Examiners on July 18, 1947, one of the members of the Committee cautioned the Commission that "the proposed rule in fact departs from the express words of the statute which, in such cases, requires the borrowed examiners to be 'selected by the Commission' instead of the mere 'approval' of de facto arrangements by agencies." 38 Despite this advice-and perhaps because of agency opposition similar to that expressed at the public hearing by the SEC representative, who felt that the proposal, far from being too loose, was too strict-the proposed section 34.12 (renumbered as section 34.10) was adopted unchanged in the first permanent regulations, issued on September 23, 1947..$^{39}$

This original regulation governed the operation of the loan program for almost fifteen years. ${ }^{40}$ During this period, loans were not frequent ${ }^{41}$ and were customarily arranged pursuant to the procedure set forth in subsection (b), rather than subsection (a), of the regulation. Typically, the agency desiring to borrow an examiner would obtain from the Commission a list of six or seven suitable candidates - that is, examiners with expertise in the field involved and from agencies likely to spare their services. The borrowing agency itself would then select one of the recommended examiners and arrange with his agency for his loan. Finally, this arrangement would

36. 12 Fed. Reg. 4233 (1947).

37. Civil Serv. Comm'n Internal Memorandum (July 16, 1947). No stenographic report of the hearing was made. See Statement by Carl McFarland Respecting the Proposed Hearing Examiner Rules, July 18, 1947 (contained in Civil Serv. Comm'n files).

38. Statement by Carl McFarland, supra note 37.

39. 12 Fed. Reg. 632I, 6324; 5 C.F.R. $\S 34.10$ (Supp. 1947).

40. It was not even amended when the Commission reissued all of Part 34 of its Regulations in 1951, although it was then renumbered as section 34.13. See 16 Fed. Reg. 9623, 9626 (1951).

41. See text accompanying note 9 supra. 
be submitted for the Commission's approval which would, of course, be granted.

The end of this simplified procedure, and of section 34.13 of the regulations, can be traced to the case of Federal Home Loan Bank Board v. Long Beach Federal Savings \& Loan Association, ${ }^{42}$ which concerned in part the validity of the appointment of one Robert $\mathrm{H}$. Hislop, an SEC hearing examiner who had been borrowed by the Board. The relevant portion of the court's opinion bears quotation at length, not only because of the legal point which it decides, but also because of the light it sheds upon the actual functioning of former section 34.13(b):

It is provided in section 11 of the Administrative Procedure Act, 5 U.S.C.A. $\S 1010$, that agencies occasionally or temporarily insufficiently staffed "may utilize examiners selected by the [Civil Service] Commission from and with the consent of other agencies." The Federal Home Loan Bank Board does not have hearing examiners and was therefore required to utilize an examiner selected by the Civil Service Commission.

Hislop's designation was arranged through the Civil Service Commission. The general counsel of the Federal Home Loan Bank Board telephoned the Commission regarding the procedure for obtaining a hearing examiner. Wilson M. Matthews, administrative officer of the hearing examiner program, suggested that the Board negotiate for the loan of an examiner from an agency permanently staffed with hearing examiners. Matthews gave the general counsel a list of names of hearing examiners experienced in financial matters. Included were names of hearing examiners permanently employed by the Securities and Exchange Commission.

The Board's general counsel then made inquiries of the SEC concerning its hearing examiners. He was informed that one of the most capable examiners permanently employed by the SEC was Hislop. The information was given that Hislop was possessed of a judicial temperament and was especially qualified in matters concerning accounting and finance. Neither the members of the Board nor its general counsel had ever met Hislop.

The Board, acting through its chairman, wrote to the chairman of the SEC requesting the loan of Hislop for service as a hearing examiner. The request was granted. The Board then requested the Civil Service Commission to give its approval, which was granted. The Board's general counsel testified before a committee of Congress that he "selected" Hislop "because he was in the Securities Exchange Commission, and I understood that he was an outstanding examiner."

There is nothing in the record to indicate that Hislop was selected on the basis of any inappropriate consideration as to his bent of mind or predisposition, and appellants disclaim any charge of personal bias against

42. 295 F.2d 403 (9th Cir. 1961). 
him. Nevertheless, the facts recited above amply demonstrate that he was not "selected" by the Civil Service Commission as required by the Administrative Procedure Act. The very essence of that act was to divorce in so far as possible the functions of prosecution and adjudication. The procedures provided are designed to accomplish this more or less mechanically and to avoid placing parties in the embarrassing and burdensome position of having to charge or prove an inappropriate commingling of these functions.

If there is any doubt as to the legality of Hislop's appointment we think the doubt should be resolved in favor of the Association. Otherwise there must be further proceedings occasioning further delay in these protracted proceedings. . . . The possibility of an error can be prevented at this stage without substantial loss of time since the administration proceeding has not yet really gotten underway.

We therefore hold that Hislop was not validly appointed as hearing examiner for this case. ${ }^{13}$

The court in Long Beach was wise to make clear that its readiness to invalidate the examiner's authority was attributable to the fact that the proceedings were still in their preliminary stages. This dictum may well have discouraged attempts to invalidate earlier decisions rendered by examiners borrowed under section 34.13 . In any event, no such attempts were made.

On July 14, 1962, only eight months after the Long Beach decision, the Commission amended section $34.13^{44}$ to what is substantially its present form. Now numbered section 930.213, it reads as follows:

At the request of an agency that is occasionally or temporarily insufficiently staffed, the Commission shall provide for the temporary use by the agency of the services of a hearing examiner of another agency. The Commission, with the consent of the agency in which a hearing examiner is employed, shall select the examiner to be used, and shall name the date on which the examiner is to be made available to the agency in need of his services. ${ }^{45}$

Under this new regulation, the following procedure for the making of loans has been employed: The borrowing agency delivers a written request to the Office of Hearing Examiners (often preceded by an informal telephone request), expressing the need for an examiner, stating the place at which and the approximate period during which the hearing in question will be held, and describing the general nature of the proceeding. The last-mentioned item of information is

43. Id. at 409-11 (footnotes omitted). The Board did not seek review of the court's decision by certiorari.

44. 27 Fed. Reg. 6693, 6969 (1962).

45. 5 C.F.R. $\S 930.213(1970)$. 
necessary for two purposes. First, it enables the Commission to determine whether the proceeding is in fact an APA proceeding, the only assignment for which the Commission has the duty or explicit authority to arrange the loan. That determination is not always easy to make, however ${ }^{46}$ and the drastic result of an erroneous judgment that section 11 does not apply is the invalidation of the proceeding conducted without a hearing examiner or with a hearing examiner selected by someone other than the Commission. ${ }^{47}$ The Office of Hearing Examiners has therefore given great weight to the judgment of the agency which requests the loan, and as far as can be ascertained it has never declined to furnish an examiner where the requesting agency has insisted that the contemplated proceeding was within the APA. Not infrequently, however, the agency which has made a request will agree, when the point is brought to its attention, that section 11 is not applicable and that a hearing examiner may be borrowed directly without the Commission's intervention.

The second reason for which the Office of Hearing Examiners requests the borrowing agency to designate the general nature of the contemplated proceeding is to enable the Commission to secure an examiner with the expertise that may be necessary or desirable. A genuine effort is made to match the man with the job. Since, for example, the hearing examiner from the Small Business Administration has considerable experience with cases involving financial matters, he has often been selected for financially oriented hearings before the Federal Reserve Board, the Federal Home Loan Bank Board, and the Federal Deposit Insurance Corporation. When the Federal Highway Administration proposed to hold hearings concerning the reduction of certain bridge tolls, the Commission selected an examiner from an agency which has experience in both rate making and land transportation matters, the Interstate Commerce Commission. And when the Bureau of Narcotics and Dangerous Drugs needed an examiner for a rule-making proceeding concerning the physiological effects of certain commercial drugs, the Commission selected an examiner who, not because of his agency experience but because of his previous background, was familiar with

46. See, e.g., Riss \& Co. v. United States, 341 U.S. 907 (1951) (per curiam), rev'g 96 f: Supp. 452 (W.D. Mo. 1950); Wong Yang Sung v. McGrath, 339 U.S. 33 (1950).

47. E.g., Federal Home Loan Bank Bd. v. Long Beach Fed. Sav. \& Loan Ass'n, 295 1×.2d 403 (9th Cir. 1961) (improperly-selected hearing examiner); Borg-Johnson Electronics, Inc. v. Christenberry, 169 F. Supp. 746 (S.D.N.Y. 1959) (non-hearing examiner). 
both the rudiments of chemistry and the nature of the pharmaceutical business.

After receiving the request, as described above, the Office of Hearing Examiners will sometimes decide upon a particular individual peculiarly appropriate for the assignment, in which case it will consult either him or his Chief Hearing Examiner, if his agency has one, to be sure of his availability. More frequently, the Office concludes that any one of the examiners from a particular agency staff would be appropriate, and it then selects a specific individual in consultation with the Chief Hearing Examiner concerned. The oral consent of the loaning agency's personnel director is then obtained. Since this is ordinarily a mere formality once the examiner or his Chief has determined that he has time available, it is frequently obtained by the examiner or his Chief rather than by the Office of Hearing Examiners itself. The Office departs from the foregoing procedure, however, when it seeks to borrow from a large examiner staff which it knows to be busy and which it therefore rarely approaches - for example, the Interstate Commerce Commission or the National Labor Relations Board. In such cases, it usually directs its initial request to the personnel director, who in turn discusses and resolves the availability of examiners with his agency's Chief Hearing Examiner and informs the Commission of the outcome.

When the identity of the loaned examiner has been determined, the Commission advises the borrowing agency. This is often done initially by telephone, but when the formal, written request of the borrowing agency is received a written reply is dispatched, naming the examiner, reciting that he has been selected by the Commission "with the consent" of the loaning agency, setting forth the commencement date and term of the loan, and stating that it will be "on a reimbursable basis." A copy of this letter is sent to the personnel director of the loaning agency.

At this point the function of the Commission in selecting the examiner under section 11 of the APA has been completed, and further details of the loan-such as arranging for reimbursement of the loaning agency, advising the examiner of the precise time and place of the hearing, and giving him copies of the pleadings, if any-are handled directly between the borrowing agency and the examiner or the examiner's agency. Copies of the Notices of Personnel Action which actually commence and terminate the examiner detail are sent to the Office of Hearing Examiners, but 
further action by the Office itself with respect to the loan will be required only if the borrowing agency seeks an extension, in which case formalities similar to those attending the original loan must be observed.

The procedures described above not only meet the objections of Long Beach, but go far beyond what that case requires. Long Beach found fault with a procedure which gave so much dominance to the borrowing agency that the Commission's role was reduced to that of a rubber stamp. The new procedure not only eliminates the dominance, but it precludes any borrowing-agency participation whatever in the initial selection process. The Office of Hearing Examiners will not accept loan requests which even suggest that a particular examiner be considered for selection.

Curiously, this punctiliousness is not observed with respect to loan extensions. Of course these pose no problem when their purpose is merely to enable examiners to complete cases they have begun. Such extensions-which comprise the only extensions sought by almost all borrowing agencies-can in no way be regarded as attempts to expand the consequences of examiner assignments which turned out to be "lucky," but are rather efforts to enable the original objectives to be achieved. An extension of this type is, one might say, within the scope of the original gamble. One agency, however, regularly requests the loan of an examiner not merely for a specific case, but for a number of cases involving the same type of matter; and it often requests an extension not only to permit the completion of pending cases but also to enable the commencement of others. ${ }^{48}$ Surely in such circumstances the request that a particular examiner be extended is no different, insofar as the observance of proprieties under section 11 is concerned, from the request that a particular examiner be appointed for loan. If the latter is considered bad form, it is difficult to understand why the former is not. The possibility always exists that an agency will seek extensions for those examiners who are regularly sympathetic to the agency's position, while allowing the loans of the more obstreperous to expire without regret. Indeed, the likelihood of the Commission's automatic compliance with a request that a particular examiner be extended is much greater than the likelihood of its automatic acceptance of the suggestion that a particular examiner be selected in the first place.

- 48. This is the Office of the Secretary of the Department of HEW, charged with the conduct of numerous "Title VI" hearings. See text accompanying notes 56-59 and 98-99 infra. 
It would seem appropriate, therefore, that the Commission adopt a policy of granting loan extensions only for the purpose of enabling examiners to complete the cases on which they are engaged, and only for the period of time necessary to accomplish that task. If an agency has a continuing need for an examiner to conduct other business, a request for loan, rather than a request for extension, should be required. It is doubtless true that in most cases, for reasons of administrative convenience, the Commission would respond by extending the loan already outstanding; and that its power to appoint an entirely new examiner despite the continuing availability of one already on loan is as theoretical as the power which it possesses under the present system to deny a request for extension despite continuing availability. The proposed policy would, however, at least have this important practical effect: When several loans are outstanding-as is often the case at HEW, for example-the choice of which to extend will rest entirely with the Commission, with no hint of the borrowing agency's preference. Moreover, even if the proposal changes nothing but form, this in itself is important when the public's confidence is at stake. The Commission's extraordinarily strict practices with respect to the original loan reflect this policy, and there is no reason why its treatment of extensions should not do so as well.

Several problems have arisen in connection with the reimbursement of agencies for the services of examiners whom they loan. This matter is not specifically treated in either the APA or the Commission's regulations pertaining to section 11. Full control of the amount of reimbursement is, however, within the power of the lending agency, since section 11 provides that it must consent to the loan. ${ }^{49}$ In practice, this matter is handled quite informally. There is rarely any negotiation between the lcnding and the borrowing agency; both understand that the former will be reimbursed for the examiner's time and travel expenses. The Commission's letter to the borrowing agency, naming the examiner and approving the loan, typically states simply that the loan will be "on a reimbursable basis," and that the borrowing agency "will reimburse [the examiner] for any travel expenses incurred in connection with the loan."

This procedure leaves several items uncertain. They are usually resolved in a spirit of cooperation and good will by the two agencies concerned, but on occasion, through burcaucratic inflexibility or

49. 5 U.S.C. $\$ 3344$ (Supp. V, 1970). 
otherwise, they have given rise to difficulty. First, there is the item of secretarial expense. After holding the hearing, the examiner returns to his own office to prepare his decision. This is often a lengthy process, consuming not only the examiner's time but also the time of his secretary in preparing the drafts which finally result in a document that may be hundreds of pages long. Lending agencies have generally billed the borrowing agencies for secretarial time as well as examiner time, and those bills have almost always been paid. On at least two occasions, however, they have not been..$^{50}$ Another difficulty arises from the vagueness of the phrase "reimbursement for travel expenses." Per diem allowances vary from agency to agency. Is the examiner to be paid according to his own agency's rules or those of the borrowing agency? On at least one occasion this problem has given rise to examiner dissatisfaction.

The reasonable resolution of these problems seems clear enough. Obviously the borrowing agency should pay for secretarial work performed for its benefit. Even then it is receiving the free use of a portion of the loaning agency's overhead. Just as obviously, the examiner should not have to accept a per diem lower than that which his own agency would accord; and he probably should receive the borrowing agency's rate if that happens to be higher, on the principle-if one is needed-that guests should be treated at least as well as family. While the agencies themselves would probably reach these conclusions if they negotiated the matter in advance, the Commission's procedures preclude any inter-agency contact concerning the particular loan until it has already been effected. Two solutions are possible: The more complicated would be the conclusion of an agreement among all agencies spelling out the details of reimbursement for hearing examiner loans. The more simple would be the inclusion of such details in a provision added to the section 11 regulations of the Commission, to be applicable to all hearing examiner loans unless otherwise specified in the loan request from the borrowing agency or in the consent of the loaning agency. Although the Commission has no power to dictate the terms of the loan, it would surely be able to adopt such a provision in order to facilitate the performance of its obligation to arrange the loan.

50. The difficulty in one of these instances arose simply because of the failure of the borrowing agency's personnel office to obtain the necessary administrative approval in advance. 


\section{Success of the Loan Provision in Achieving Its ObJectives}

The purposes of the Ioan provision are not discussed at any length in the legislative history of the APA itself, ${ }^{51}$ but the Report of the Attorney General's Committee, in which the Ioan provision originated, contains an extensive explanation:

(b) Provisional and temporary appointments. ...

The appointment of temporary hearing commissioners may be necessitated by different considerations. Sudden increases in the number of cases which must be heard at a given time may be of only a temporary character, not justifying the appointment of another hearing commissioner for a 7-year term. ${ }^{52}$ Similarly, one or two unusually protracted proceedings may so reduce available hearing personnel that dockets become congested with other cases. To prevent the accumulation of backlogs, and to dispose of them as rapidly as possible when they do occur, the Committee finds it desirable to permit agencies, in such a situation, to appoint temporary hearing commissioners, either by the temporary assignment of hearing commissioners from other agencies or by the temporary appointment of persons who meet with the approval of the Office of Federal Administrative Procedure. . . .53

Furthermore, in some agencies, the volume of cases may be so small that the appointment of a regular hearing commissioner may not be justified. The Federal Reserve System has held less than a dozen formal adjudicatory hearings since 1914; the Federal Deposit Insurance Corporation has held only 22 hearings in three years; the War Department has set rates for a total of only 50 toll bridges, and often not a single rate hearing is held in the course of a year. In agencies whose work load is as light as these, there are insufficient cases to occupy a permanent hearing commissioner devoting his entire time to hearing and deciding. The Committee, accordingly, does not recommend the addition of regular hearing commissioners in such agencies. Instead, it is contemplated that the agencies in which formal adjudication is a more or less inconspicuous and inconsequential adjunct of other activities, will select temporary hearing officers, as outlined above, to conduct and decide cases as they arise.

(d) Exchange of hearing commissioners. - While, as stated, each hearing commissioner should be attached to a particular agency whose cases he is to hear and decide, it should not be necessary that under all circumstances he devote his entire energies to that agency. Rather, insofar as the several agencies desire and request it, there should be permitted an interchange of hearing

51. The only discussion is contained in the brief excerpt from the Report of the House Committee on the Judiciary quoted in the text accompanying note 33 supra. It amounts to little more than a restatement of the statutory provision.

52. The Report of the Attorney General's Committee recommended that hearing examiners be appointed for only seven year terms. ATT'Y Gen. REP. 46.

53. The Report of the Attorney General's Committee recommended the creation of an Office of Federal Administrative Procedure, whose responsibilities would have included those ultimately assigned to the Civil Service Commission under section 11 of the APA. Id. at 46-49. 
commissioners among the agencies. Thus, for example, cases arising under the Commodity Exchange Act probably will not justify the Department of Agriculture's appointment of a full-time hearing commissioner, yet hearing commissioners at the Securities and Exchange Commission should be well qualified to hear Commodity Exchange Act cases. Similarly, the same hearing commissioner might well be able to hear cases arising both under the National Labor Relations Act and violation cases under the Walsh-Healey Act; or the same commissioner may be qualified to hear misconduct cases coming both before the Bureau of Marine Inspection and Navigation and the Civil Aeronautics Board. Interchange of this nature is desirable because it would reduce the use of temporary hearing officers; it would save expense; it would provide some variety for the hearing commissioner; and it would impart fresh points of view to the agencies. . ...5

The loan program has generally fulfilled the Committee's expectation that it would prevent the hiring of hearing examiners by agencies with insufficient work to employ them full time. Subsequent history of the three specific illustrations given in the Committee's Report exemplifies this point. Neither the Federal Reserve Board nor the Federal Deposit Insurance Corporation has ever appointed its own APA examiner; both agencies have been recurrent borrowers since the Act came into effect. The bridge-toll cases referred to in the Committee's Report have been transferred from the jurisdiction of the former War Department to the Federal Highway Administration, ${ }^{65}$ but since that agency likewise has no hearing examiner of its own they are regularly heard by a borrowed examiner.

The outstanding example of the manner in which the Office's intelligent use of the loan provisions has avoided the needless creation of hearing examiner positions in additional agencies is to be found in the developments following enactment of Title VI of the Civil Rights Act of $1964 .{ }^{56}$ This prohibited discrimination in all federally assisted programs and directed that each federal agency extending federal financial assistance to any program enforce the prohibition. The principal means of enforcement provided was "the termination of or refusal to grant or to continue assistance under such program or activity to any recipient as to whom there has been an express finding

54. Id. at 48-49.

55. The bridge-toll regulating functions of the Secretary of the Army, contained in 33 U.S.C. $\$ \S 491-534$ (1964), were transferred to the Secretary of Transportation by the act which created that Department. 49 U.S.C. $\$ 1655(\mathrm{~g})(4)$ (Supp. V, 1970). The Sccretary of Transportation has in turn delegated them to the Federal Highway Administrator. 49 C.F.R. $\S 1.4(\mathrm{c})(10)(1970)$.

56. 42 U.S.C. $\S 2000 \mathrm{~d}(1964)$. 
on the record, after opportunity for hearing, of a failure to comply. ..." ${ }^{57}$ Of course the underscored language brought the proceeding under section 5 of the APA and, by virtue of section 7, required it to be held before a section 11 hearing examiner. But the vast majority of agencies administering federal assistance programs-including the Department of Defense, the Office of the Secretary of Health, Education and Welfare, the Department of Housing and Urban Development, the Office of Economic Opportunity, and the Social and Rehabilitation Service-did not have any hearing examiners. As these agencies began to draw their regulations for implementation of Title VI, the Office of Hearing Examiners began to receive inquiries concerning the establishment of new hearing examiner positions. It assured the agencies that, at least until the volume of anticipated hearings could be more accurately ascertained, it would be able to meet their needs through the loan program, and persuaded all of them to forego the appointment of their own examiners for the time being. The Office asked each of the agencies with large examiner staffs to designate in advance examiners who would be available to assist in the initial flood of Title VI work. About half of the examiners so designated were given a two-week course by the Department of Health, Education and Welfare concerning the substance, policies and procedures of the Civil Rights Act of 1964 and applicable regulations. ${ }^{58}$ These examiners later conducted numerous Title VI hearings in various agencies and enabled the Act to be fully implemented without the creation of a single new hearing examiner position for that purpose..$^{59}$

The loan program's utility in achieving an efficient use of highly skilled manpower also has an inverse aspect not specifically mentioned by the Attorney General's Committee. The program is,

57. Id. $§ 2000 \mathrm{~d}-1$ (1964) (emphasis added).

58. This initial group comprised approximately 25 examiners. A similar course was originally planned for the other 25 examiners who had been designated for the "Title V1 pool," but it was found that the first group was sufficient to handle all the hearings. Some litigants and public officials objected to the Title VI course as an improper "indoctrination." Since, however, the course was not conducted with reference to any specific case or fact situation, it appears unobjectionable.

59. It is probably true, however, that the examiner staff of the Social Security Administration has been increased beyond its normal nceds in order to enable it to bear the brunt of the Title VI loan business. The original "Title VI pool" is no longer functioning, and the Title VI work is now almost invariably assigned to examiners from the Social Security Administration, who have likewise been given special training for that purpose. See text accompanying notes 97-99 infra. 
one might say, twice blest-it blesses him that gives, and him that takes. ${ }^{60}$ Not only is it a boon, as the Attorney General's Committee foresaw, to the agency in temporary need of an examiner; it also benefits the agency which faces a temporary shortage of APA work for its examiners to perform. To be sure, if the agency wishes to do so, it may assign such examiners to other work not inconsistent with their functions. ${ }^{61}$ But there is not often a great surplus of such work requiring the abilities of a person with the hearing examiner's grade level. The only economic alternative is a reduction in force. ${ }^{62}$ Even when this does not occur, if the other duties to which the examiner is assigned require a lesser degree of ability, and if his remaining hearing examiner duties do not include a substantial amount of work of that level of difficulty which justifies his grade classification, the Commission may be compelled to down-grade the position. ${ }^{63}$ In those agencies with large examiner staffs, these severe consequences can usually be avoided by distributing the non-APA work evenly among all the examiners; but when an agency with merely one or two examiners $^{64}$ is faced with a sudden drop in APA work, that solution is not available. Moreover, it is not impossible for even an agency with a large staff to be confronted with such a precipitous decline in the

60. Cf. W. Shakespeare, The Merchant of Venice, Act IV, Scene 1.

61. Such detail cannot be extended beyond 120 days in any 12 -month period without the Commission's consent. See text accompanying note 23 supra.

62. The security which section 11 of the APA extends to hearing examiners' tenure does not prevent a reduction in force. Ramspeck v. Federal Trial Examiners Conf., 345 U.S. 128, 140-42 (1953). Under the Commission's regulations, however, any examiner who is affected by such a reduction has a right to fill the next hearing examiner vacancy which appears at his own, or any inferior, grade level in any agency - even despite his failure to meet the selective certification requirements for the position. 35 C.F.R. $\$ 930.215$ (1970).

63. Apparently the Commission cannot, however, eliminate the hearing-examiner character of the position, with all the special protections which that affords, so long as some portion of the individual's duties involves the hearing of APA cases. The regulations define a "hearing examiner position" as one "in which any portion of the duties includes those which require the appointment of a hearing examiner under section 3105 of title 5, United States Code." 35 C.F.R. $§ 930.202$ (c) (1970). This, incidentally, is the reason the Office of Hearing Examiners has insisted that all Chief Hearing Examiners, many of whom could profitably devote their entire time to matters of administration and coordination, preside over at least one APA hearing each year. In one respect, it is worse for an examiner to be down-graded than to fall victim to reduction in force, since only in the latter situation do the regulations insure him appointment to the next hearing-examiner vacancy at his old grade. See note 62 supra.

64. At present, the Civil Service Commission, the Small Business Administration, and the Alcohol \& Tobacco Tax Division of the Bureau of Internal Revenue have only one cxaminer. The Food \& Drug Administration, the Post Office, the Department of Labor and the Maritime Administration have only two examiners. 
amount of its APA hearing business that the available work, even if distributed evenly among the staff, would not be sufficient to justify the maintenance of the same examiner force or to avoid a downgrading. In 1951, for example, it was the separation of eight hearing examiners from the National Labor Relations Board which gave rise to the case of Ramspeck $v$. Federal Trial Examiners Conference. ${ }^{65}$ Needless to say, aside from the foregoing considerations of economy and the jeopardizing of employment tenure, lengthy periods of time in idleness or in the performance of non-examiner functions are destructive of examiner morale and professional pride. The loan program has proved to be a solution to all of these difficulties - indeed, as will be discussed in a later section, perhaps too ready a solution. ${ }^{66}$ The agency facing a sudden decline in its APA business need not make the choice between a reduction in force or serious economic waste; it can be reimbursed for those portions of its examiners' salaries attributable to loan work. The Commission need make no reclassification of an examiner who continues to spend most of his time in APA hearings, even though many of those hearings may be before agencies other than his own. And the examiner himself not only suffers no impairment of self-respect, but actually increases both his abilities and his sense of professionalism through exposure to novel and challenging situations.

Another of the benefits which the Attorney General's Committee expected to result from the loan program-though doubtless a merely secondary benefit-was that "it would provide some variety for the hearing commissioner." 67 This hope also has been fully realized. The lists of borrowing and loaning agencies presented above give good indication of the extent of interchange which has been achieved. There is no question that the hearing examiners find this beneficial. In the numerous interviews which were conducted in connection with the present study, and which form the basis for the conclusions and recommendations set forth in later sections of this article, ${ }^{68}$ the hearing examiners without exception expressed enthusiasm for the loan program, principally because of the variety which it provides. The value of this variety should not be underestimated. Conceding the

65. 345 U.S. 128 (1953). See Macy, The APA and the Hearing Examiner: Products of a Viable Political Society, 27 FED. B.J. 351, 373-74 (1967).

66. See pp. 358-59 of text infra.

67. ATt'y GEN. ReP. 49.

68. See pp. 356-66 of text infra. 
worth of specialization, an examiner nevertheless reaches a point at which he will function more efficiently in his specialized field if he is given a change to hearings with a different factual and legal content. The attentiveness and flexibility which an examiner must maintain are stimulated by an occasional alteration of intellectual diet. The need for such variation through the loan program doubtless is not equally acute in all agencies. Examiners at the Federal Trade Commission, for example, are exposed to more diverse matters in the course of their regular duties than are examiners at the Federal Power Commission. But it is believed that examiners in all agencies can profit from an occasional shift to completely different subject-fields. Of course this beneficial diversity could be provided by regularly assigning each examiner to a different sort of intellectual task within his own agency. ${ }^{69}$ But in addition to being wasteful of the examiner's unique talents, such a solution would fail to achieve another benefit which arises from providing the variety through the loan program: the heightening of professional pride. A loan brings home with special force the point that the hearing examiner job is not an assembly-line activity, but rather a function that requires, in addition to specialized knowledge, the breadth, adaptability, and general competence of the true professional. Those examiners who have been active in the loan program claim to have acquired, and to have imparted to their colleagues, an increased awareness of the importance of their duties, the skill required to perform them properly, and the constant effort and self-discipline necessary to avoid that intellectual stagnation which is the major obstacle to every sort of professional excellence.

In another respect, however, the loan program has fallen far short of the expectations of the Attorney General's Committee. It has in general not been used, as the Committee had hoped, by those agencies which have hearing examiner staffs of their own, to handle intermittent overloads-or, in the Committee's language, "[t]o prevent the accumulation of backlogs, and to dispose of them as rapidly as possible . . ."."70 Borrowings by agencies with their own staff have been extremely rare. ${ }^{71}$ This phenomenon is explicable by the

69. This is permissible so long as the duties are not "inconsistent" with his duties as a hearing examiner, and so long as the term of the detail does not exceed 120 days without the Commission's consent. See text accompanying notes 19-23 supra.

70. ATT'Y GEN. REP. 48.

71. This statement excludes the NLRB borrowings discussed above, which are not for the agency's internal use. See text accompanying notes 25-31 supra. 
need for hearing examiner specialization felt by those agencies which have a regular enough hearing business to require their own staff. Or, the opponents of selective certification ${ }^{72}$ might say, it may be explained by the reluctance of those agencies which employ selective certification $^{73}$ to cast doubt upon the genuineness of their need for specialization by making use of unspecialized borrowed examiners. ${ }^{74}$ That some connection exists between the need for specialization-or the need to appear to desire specialization-and the infrequency of borrowing by staffed agencies is suggested by the fact that almost all of those infrequent borrowings have involved examiners who were formerly employed by the respective borrowing agencies, or who were in process of, or under consideration for, transfer to those agencies. ${ }^{75}$

Finally, as a direct result of the rarity of borrowing by staffed agencies, it must be concluded that another hope of the Attorney General's Committee for the loan program has not been substantially realized. The Committee's expectation that the program would

72. Selective certification is the procedure whereby the Commission allows an agency which so requests, and which justifies its request to the Commission's satisfaction, to select its hearing examiners from a Selective Register which lists only those candidates who have specialized experience in the field which that agency regulates. This usually enables the agency to select candidates whose ranking on the General Register is too low to permit them to be selected under the normal rules. See generally Hearings on Selective Certification Method of Appointing Hearing Examiners Before a Subcomm. of the House Comm. on Government Operations, 86th Cong., 2d Sess. (1960) [hereinafter cited as Selective Certification Hearings]. From the commencement of its use in 1953 to the present day, the selective certification procedure has been the object of severe criticism from several quarters, including the Federal Trial Examiners Conference and the American Bar Association. See, e.g., Miller, The Vice of Selective Certification in the Appointment of Hearing Examiners, 20 AD. L. REv. 477 (1968).

73. Only about half of all agencies which have their own examiner staffs use selective certification. This number includes, however, all the major regulatory agencies except the FTC and all agencies with examiner staffs more numerous than 12 except the Social Security Administration. Although the last mentioned agency has by far the largest examiner staff in the federal government (approximately 300), it has been adding examiners with such regularity in recent years that it has not found it necessary to borrow. Not including the Social Security Administration, only about 50 of the remaining 320-odd examiners are in non-selective certification agencies. Thus, a reluctance to borrow on the part of selective certification agencies alone would have significant effect upon the frequency of borrowings by all staffed agencies in general.

74. The generally successful operation of the loan program is sometimes cited as evidence that selective certification is not necessary. See, e.g., Selective Certification Hearings 15-17. The point would have more force if the very agencies which asserted a need for specialization-that is, those employing selective certification-made regular use of borrowed examiners.

75. Under the loan procedures employed by the Commission prior to 1963, the borrowing agency could select the examiner it desired. See text accompanying notes 35-43 supra. This powcr was sometimes employed to obtain immediate use of an examiner whose transfer was still in process or even to try out a particular examiner in order to determine his suitability for hiring. 
"impart fresh points of view to the agencies" primarily to those interchanges concerning the procedures and techniques of the hearing process which could be expected to occur between the loaned examiner and the members of the examiner staff to which he is temporarily assigned. When there is no such staff, there is no such interchange. The contacts between a loaned examiner and non-examiner members of the borrowing agency are of course infrequent and superficial, except those formal contacts which occur during the course of the hearing. Moreover, between officials whose functions are so different, there is little common ground to discuss. It may be added that the desired interchange of ideas among examiner staffs has been pursued through means other than the loan program-such as the Annual Seminar conducted by the Federal Trial Examiners' Conference in conjunction with George Washington University and the training sessions for hearing examiners conducted by the Civil Service Commission several times each year at Williamsburg, Virginia.

\section{Disadvantages of the Hearing Examiner Loan}

The principal benefits of the loan program have been alluded to earlier. The system also has its disadvantages, a few of which might perhaps be divined from an armchair, but some of which can only be discerned by collecting and evaluating the judgments of a large and reprcsentative number of persons who have been directly involved with hearing examiner loans. The ensuing discussion is the result of an attempt at just such a collection and evaluation. It is based upon numerous interviews with agency heads, members of agency staffs, chief hearing examiners, hearing examiners and private attorneys-all from various fields of administrative law. Though the scheme of interviews was intended to be representativc rather than exhaustive, it is believed to have included almost all examiners who have been loaned with any frequency, all chief hearing examiners from agencies which have loaned examiners with regularity, and one or more staff members from all agencies which have borrowed with regularity. In the following discussion, no attempt will be made to substantiate each statement concerning experience under the loan program by the citation of a particular interview; for except as otherwise indicated,

76. ATT'Y GEN. REP. 49. 
none of such statements is based upon an isolated opinion, but each is rather the informed consensus.

\section{Mistrust on the Part of Potential Borrowing Agencies}

The first disadvantage from which the loan program suffers is that it does not seem as good as it is. There is an inherent, and probably irremediable, credibility gap. Hearing examiners, like judges or professors, are not fungible; some are better than others. In point of fact, those examiners who have participated most frequently in the loan program are among the most respected. Those relatively few agencies which have borrowed with regularity, and whose personnel in charge of arranging loans have remained constant, are aware of this. But among the uninitiate and the inexperienced, the conventional wisdom is that a borrowed examiner will not be of the highest caliber.

One can hardly blame the agencies which harbor this groundless suspicion, nor can one expect them to abandon it entirely, despite any accumulation of evidence to the contrary. For as a matter of fact, the suspicion is based upon a very accurate assessment of administrative, not to say human, propensities: The agency which must loan an examiner is obviously not going to loan its best man, but will rather loan the man whom it can best do without. The only reason the suspicion has not been substantiated by the facts in recent years is that no agency has had to loan an examiner. Since several agencies have had examiners in positive need of APA work, no arm-twisting or inveiglement has been required to induce the grudging loan of a member of an overburdened staff. To the contrary, in most cases the loan has been as desirable for the lender as for the borrower. ${ }^{77}$ If and when this is no longer the case, there is no doubt whatever that, as the Chief Hearing Examiner at one agency acknowledged, the loaned examiner will not be one of the best men on the staff. But regardless of whether that situation presently exists, no amount of persuasion or demonstration is likely to eliminate the belief, at least in many quarters, that a borrowed examiner is inferior in ability to one's very own. The effect is to induce some agencies to create or increase their

77. See text accompanying notes 60-66 supra. The one recent exception to this proposition may be some of those loans arranged for the purpose of establishing the "Title VI pool" discussed in text accompanying notes 56-59 supra. Some of the members of that pool came from regulatory agencies which had no surplus of examiner manpower. The early Title Vl cases had high political visibility, however, and strong pressure from the White House tended to assure not only that the loans were made, but that the best personnel were provided. 
own examiner staffs much earlier than their volume of work really requires.

\section{The Borrowed Examiner's Lack of Special Knowledge}

The second disadvantage inherent in the loan program relates not to the actual or suspected raw ability of the borrowed examiner, but to his acquired knowledge. It is not germane to the present study to argue the merits of specialization. 1ts value is, after all, not absolute and may be outweighed by other considerations, such as the increased appearance of impartiality which use of a borrowed examiner can lend to a hearing. ${ }^{78} 1 \mathrm{t}$ is the case, however, that specialization and the bringing to bear of accumulated "expertise" are among the accepted reasons for the very existence of administrative-as opposed to judicial-rule making and adjudication. And whatever those reasons are worth, their force is without doubt greatly reduced in hearings conducted under the loan program. Except where the Office of Hearing Examiners is able to obtain for loan an examiner who was previously employed in the borrowing agency, or who has expert knowledge in the subject field acquired in some other manner, the borrowed examiner knows no more than the general practitioner about the substantive and perhaps even the procedural rules he is to apply.

Nor can the borrowed examiner's familiarity with the policies, practices, and procedures of the agency be increased by a short "cram course" conducted by the borrowing agency itself. Since his detail is for the purpose of hearing one specific case, any such "briefing" would be understandably objectionable to the private litigant, even if conducted without explicit reference to the facts of the particular case. ${ }^{79}$ For this reason, borrowing agencies limit their contact with the examiner to advising him of the time, place, and subject matter of the proceeding and furnishing him with copies of the applicable statute, regulations, and rules of procedure ${ }^{80} \mathrm{~A}$ vivid, if greatly atypical,

78. Several practitioners who were interviewed observed that, whether or not it was true, they could not avoid feeling that their cases would receive a fairer hearing from examiners who did not come from within the agency itself.

79. Although such a "briefing" by the Chief Hearing Examiner of the borrowing agency, as opposed to its staff, would be less offensive, it still seems inappropriate since it would be done with the particular case in mind. Moreover, as noted above, very few loans are made to agencies which have their own examiner staffs.

80. An interesting exception to this general practice exists in that class of loans which has been made to the United States Board of Parole for the purpose of holding hearings under 
illustration of what may happen as a result of the borrowing agency's inability to give the examiner even a rudimentary orientation is contained in the following account: The proceeding for which the examiner had been borrowed was strictly pro forma-an entirely unopposed application that the agency, in excessively strict adherence to the letter of its statute, required to be disposed of "after a hearing and on the basis of the record thereof." The agency staff had reviewed all of the items with the applicant and found them satisfactory, and no private interests had sought to appear in opposition. Counsel for the applicant, being somewhat new to the field, asked the agency staff what matters he should introduce at the hearing. The staff permitted him to scan the records of earlier proceedings and made some specific suggestions as well. In reply to the borrowed examiner's pre-hearing request for disclosure of the general nature of the evidence, applicant's counsel imprudently stated that he planned to introduce certain items "at the suggestion of the agency staff." The examiner was profoundly shocked and sent an irate letter to the responsible staff member, censoring his improper "collusion." This particular incident was doubtless not handled with the utmost finesse by any of the parties concerned; but the opportunity for such a comedy of errors was provided by the inevitable effect of the loan program, as currently operated, in preventing even rudimentary education of the examiner in the business of the agency.

Aside from such extraordinary incidents, however, it would be a mistake to make too much of the extent to which the loan program suffers from the lack of expertise on the part of borrowed examiners. Almost by definition, those agencies which do not have their own examiner staffs, and therefore must borrow, are not agencies which hold hearings of the type in question with much frequency. Thus, there

section 504(a) of the Labor-Management Reporting and Disclosure Act of 1959, 29 U.S.C. $\S 504$ (a) (1964). This provides, in relevant part, that no person convicted of certain crimes may serve in certain capacities as an employee of a labor organization for a period of five years after his conviction or imprisonment, unless the Board of Parole determines after an administrative hearing that such employment would not be contrary to the purposes of the Act. It has been the practice for a member of the staff of the Board of Parole to discuss with the borrowed examiner the policies and purposes of the Act, the factors considered relevant by the Board to the exercise of its discretion, and the procedures used in the conduct of the hearing. A crucial distinction between these hearings and others, however, is that the Board has no function under the Act except in connection with these hearings, and its function there is solely adjudicative. The Application for a Certificate of Exemption is never opposed in the hearing by any member of the Board's staff; this task falls to the Secretary of Labor, who has general responsibility for enforcement of the Act. 
often does not exist a vast amount of "expertise" to be acquired. The Federal Highway Administration, for example, has only held two bridge-toll hearings in recent years, and it seems improbable that anyone within the agency itself is steeped in knowledge on the subject. Nor is the United States Board of Parole particularly teeming with experts on the Labor-Management Reporting and Disclosure Act of 1959. In such situations the borrowed examiner's disadvantage is a small one, and could be eliminated entirely if there were only an opportunity for a brief orientation. To be sure, the hearings of some agencies, although infrequent or rare, pertain to subject-matter which is highly technical and is also the everyday business of the agency; in these instances the borrowed examiner's newness to the field is apparent, at least in the early stages of the hearing, and observers say it has the effect of slowing the proceeding and expanding the record somewhat. But the private practitioners consulted feel that even here the borrowed examiner who is experienced in the process of conducting a hearing is more satisfactory than a new examiner who may be an expert in the agency's field but is a novice at presiding. Finally, it should also be recalled that the Office of Hearing Examiners does make an effort to secure, wherever possible, an examiner who has the required expertise-often through earlier hearings conducted on loan to the same agency. In short, the disadvantage of lack of expertise does exist under the loan program and can never be entirely eliminated; but it is generally so small a disadvantage as to be outweighed by the other benefits which the program produces.

\section{The Borrowed Examiner's Invisibility}

Another disadvantage of the loan program, and one which is considerably more serious, may be described by the word "invisibility." The hearing examiner, even when he is not on loan, is and properly should be one of the most independent of governmental officials. His agency has power neither to reward him with promotion $^{81}$ nor to punish him with demotion or dismissal ${ }^{82}$ unless his

81. See 5 U.S.C. $\$ 5362$ (Supp. V, 1970). One small exception to this statement may exist. The Attorney General has held, overruling the opinion of the General Counsel of the Commission, that an agency has the power to select its own Chief Hearing Examiner-a position which ordinarily carries a grade level one step higher than that for the examiner staff in the particular agency. See 42 OP. ATT'Y GEN. No. 19 (1964). While it is at least questionable whether the courts would sustain this position, the Commission has not chosen to contest the point, and it is difficult to imagine a private litigant's raising it.

82. See 5 U.S.C. $\$ \S 5362,7521$ (Supp. V, 1970). As noted in note 62 supra, an examiner 
misconduct is so grievous as to support formal APA removal proceedings before the Civil Service Commission. ${ }^{83}$ Moreover, even the power to promote hearing examiners which was given to the Civil Service Commission by section 11 of the $\mathrm{APA}^{84}$ has become a purely theoretical one, since in recent years the Commission has implemented a policy of establishing a single grade for all examiners within each agency. ${ }^{85}$ The result is that-short of incompetence or

may be dismissed when there is a reduction in force; but this power cannot easily be directed against a particular examiner, since "RIF" dismissals must, under the governing law, be conducted strictly on the basis of seniority and veterans' preference. 5 C.F.R. $\$ 930.215$ (I970).

Of course, the agencies have at their disposal more subtle means of being nasty or nice to their examiners. Hearing examiners in various agencies have at times complained that such agency actions as the elimination of parking privileges or reduction in the amount of secretarial assistance were unlawful as compromising the examiners' independence. Presumably to protect themselves and the Republic from the possibility of such undue influence, in 1968 the Federal Trial Examiners Conference adopted and recommended to the Commission a set of Standards for Federal Hearing Examiner Office Space, Equipment, Supplies, Facilities, and Staff which go into almost microscopic detail: "Bookcases (4), 5-sectional . . . Carpeting, wall-to-wall . . . Staplers, hole punchers, and other standard office equipment, all new or modern and in working condition . . . Agency stationery and envelopes imprinted with Hearing Examiner name and title . . . Legal size briefcase of adequate capacity, lockable, new . . . No Federal Hearing Examiner shall at any time be required or requested to waive any of these standards." As far as is known, however, there has never been any serious suggestion that the granting of amenities or the imposition of inconveniences has been used to reward or punish particular examiners for the character, the quality, or the quantity of their opinions. This particular issue of agency influence through the granting or withholding of logistical support seems likely to be raised again by one staff of examiners in the near future, since the Social Security Administration is considering a plan which would not cut secretarial assistance across the board, but rather allocate it on the superficially reasonable basis of the number of opinions which each examiner produces each year (in that agency there is extraordinary variation).

83. See 5 U.S.C. $\$ 7521$ (Supp. V, 1970); 5 C.F.R. $\$ \S 930.22$ I-.234 (1970). Only four such proceedings have been instituted since enactment of the APA in 1946.

84. 5 U.S.C. $\S 5362$ (Supp. V, I970).

85. This policy was strongly advocated by the Hearing Examiner Committee of the ABA Section on Administrative Law, by the Commission's own Advisory Committee, and by the Federal Trial Examiners Conference. The only agency which now has examiners of varying grade levels is the Office of the Secretary of Interior, where Indian Probate examiners are GS-I3 and other examiners (who do mainly Bureau of Land Management work) are GS-15. This twograde staff was created very recently, as a result of the transfer to the Office of the Secretary of the two separate staffs which formerly were lodged within the Bureau of Land Management and the Bureau of Indian Affairs, respectively.

It is not meant to imply that abandonment of the old multi-grade system deprived the world of an efficient and effective means of rewarding quality and quantity of examiner performance. To the contrary, the very nature of the statutory framework rendered the device unworkable. On the one hand, the Civil Service Laws require grade level to be determined by the level of difficulty, level of responsibility, and qualification requirements of the work assigned. See 5 U.S.C. $\$ 5106$ (Supp. V, 1970). On the other hand, section II of the APA requires cases to be assigned among hearing examiners "in rotation." 5 U.S.C. § 3105 (Supp. V, 1970). The combination would appear to render the Commission's power to prescribe pay ( 5 U.S.C. 
neglect of such magnitude as to support removal proceedings-hearing examiners are accountable to no one. Although some disagreement may exist as to the wisdom of this arrangement, it is little different from the complete independence accorded federal judges. If non-accountability is an evil, perhaps it is a necessary one, to assure judgments free from any taint of influence.

But despite the lack of formal accountability, it would be false to imagine that hearing examiners, and judges, are free from any inducement to excellence other than the strength of their own character. First, both are subject to the approbation or contempt of their professional colleagues. In most agencies examiners work in close proximity to at least some other members of the examiner staff, and in many cases the lawyers who practice before them are a small and highly specialized bar. In the larger regulatory agencies, at least, the examiners' opinions are published in a regular series of reports which receives relatively wide circulation. Under such circumstances, each examiner will inevitably create for himself a reputation on the basis of the work which he produces; and a man of the professional caliber to qualify for an examiner position may be expected to care about this reputation, even if it does not mean money in his pocket or the loss of his job. In addition, almost every agency with more than ten examiners has a Chief Hearing Examiner who is personally responsible for the quality and quantity of his staff's performance, and who, unlike the agency staff, is not prohibited from discussing such matters with the examiners. ${ }^{86}$ Although he possesses no power to sanction, he can advise, persuade, cajole, and even shame the deficient staff. As matters have developed he is, practically speaking, the only formal, institutional control over the examiner's performance.

It will be immediately noted that each of these inducements to maximum effort is greatly reduced, or nonexistent, in the case of an examiner loan. The work of a borrowed examiner is performed,

$\S 5362$ (Supp, V, 1970)) illusory, except insofar as it may apply to elevation or reduction of the grade level of an entire examiner staff. Although the Supreme Court managed a reconciliation of the apparent inconsistency in Ramspeck v. Federal Trial Examiners Conf., 345 U.S. 128, 139-40 (1953)-holding that the rotation was to occur within each separate category of case difficulty -that reconciliation was more logical than practical. The Commission ultimately found the task of kecping each agency's hearing work divided into discrete categorics of complexity utterly unmanageable.

86. For a description of the duties of a Chief Hearing Examiner, see 42 OP. ATT'Y GEN. No. 19, at 4-6 (1964). These include "a major responsibility . . for providing necessary professional leadership, guidance, training and direction" to hearing examiners. Id. at 5. 
generally speaking, before a nonspecialized bar, and his opinion is generally not published in any form which receives circulation beyond the agency and the private litigants involved. In such circumstances, the character of his work is not likely to win him a reputation; or, if so, not one which will follow him back to the circle in which he spends almost all of his professional career. Nor is there a Chief Hearing Examiner to observe and comment upon his performance. ${ }^{87}$

\section{The Borrowed Examiner's Lack of Identification with the Borrowing Agency}

The final disadvantage of the loan system which bears mention is the borrowed examiner's lack of identification with the interests of the agency to which he is assigned. In point of fact this may, on balance, be more of an advantage than a disadvantage. But that battle was fought and decided many years ago, and the resolution was that it was important where feasible for examiners to be part of the agency itself.

The method by which the hearing commissioners and their chiefs should be selected presents a perplexing problem. Suggestion has been made that they be a separate corps, not attached to specific agencies, and that they be appointed, perhaps for life, perhaps for a specified term, by the President, by and with the advice and consent of the Senate. The [Attorney General's] Committee [on Administrative Procedure] has given careful and searching consideration to this and similar suggestions and has concluded that they are not desirable. ... .

[T] he hearing commissioner is in a very real sense acting for the head of the agency. He is hearing cases because the heads cannot as a practical matter themselves sit. He plays an essential part in the process of hearing and deciding. . . . 8 s

The purpose of [section 11 of the APA] is to render examiners independent and secure in their tenure and compensation. The section thus takes a different ground than the present situation, in which examiners are mere employees of an agency, and other proposals for a completely separate "examiners' pool" from which agencies might draw for hearing officers. ${ }^{89}$

87. Not infrequently, a loaned examiner will submit a copy of his opinion to the Chief Hearing Examiner of his own agency, but this serves primarily the function of documenting the examiner's expenditure of time away from his ordinary duties. It would be unrealistic to expect the Chief Hearing Examiner to take time from his proper cares to supervise the quality and quantity of work done on loan. Moreover, as noted above, the Chiefs power rests entirely upon the prestige and affection which he commands, and his persuasive ability-all of which are diminished when he steps into fields not committed to his charge.

88. AtT'Y GEN. REP. 47.

89. RePORt OF THE CoMm. ON the Judiclary ON S. 7, S. ReP. No. 752, 79th Cong., lst Sess. 29 (1945), reprinted in APA: Legislative History 215. 
The provision of section 11 that examiners shall be appointed "by and for each agency" 90 is the result, at least in part, of a feeling that those who are "acting for the head of the agency" should have an identification with the goals and policies of that agency. In some examiner staffs, the reality and the benefit of that identification is apparent; there is a noticeable esprit, a feeling of pride in, and responsibility for, the achievements of the agency, and a determination to maintain high standards in order to contribute to the team effort.

In the loan provision of the APA, however, the value of "identification" is sacrificed to other values such as economic efficiency. The borrowed examiner has no special commitment to the successful achievement of the goals of that agency to which he is temporarily assigned. While the advantages of this judicial detachment are apparent, it must also be recognized that there are palpable disadvantages. It is peculiar, and probably significant, that of the relatively small number of loan cases specifically discussed and examined in connection with the present study-certainly no more than thirty-no less than three contained criticism, intentional disregard, or invalidation of the borrowing agency's governing statute, its policies, or its regulations. In one, the governing statute was enforced with the opinion that it was probably unconstitutional; in a second, a clear line of agency decisions was deliberately ignored as being contrary to the governing statute; ${ }^{22}$ and in a third, the agency's regulations were held to be ultra vires. ${ }^{93}$ No attempt was made to examine all, or even an intentionally representative sampling, of the opinions of loaned examiners. But even on a haphazard basis, encountering such a high proportion of decisions against the agency - on the basic law rather than the facts-gives one cause to wonder. The point is not that the borrowed examiners in these cases were wrong; substantively, they may well have been correct, even

90. Act of June 11, 1946, ch. 324, § 11, 60 Stat. 244. The corresponding provision of the current law reads "each agency shall appoint . . . hearings [sic] examiners." 5 U.S.C. $\S 3105$ (Supp. V, 1970).

91. In re Drouin, Application No. L-23 (U.S. Bd. of Parole 1967) (hearing examiner recommended decision).

92. In re United Virginia Bankshares, Inc., 56 Fed. Res. Bull. 602 (No. BHC-98) (hearing examiner recommended decision), recommendation rejected, 56 Fed. Res. Bull. 599 (Fed. Res. Bd. 1970).

93. In re Calhoun County (S.C.) School Dist. No. I, No. CR-206 (Off. of Ed., H.E.W., 1967) (hearing examiner recommended deeision holding Guidelines issued under Title VI ultra vires). The recommendation was rejected by the Office of Education (unpublished). 
despite the subsequent agency reversals. But the frequency of decisions of this type among the admittedly small sampling confirms the impression which this writer received from the numerous interviews conducted: The borrowed examiner approaches his case with an attitude significantly different from that of an examiner sitting within his own agency -an attitude closer to that of an appellate court than of one who is "acting for the head of the agency." For better or worse, his decision is somewhat less of an "agency decision," with the cohesiveness of purpose which that phrase implies; and somewhat more of an objective judicial determination, giving the agency the benefit of no legal doubts, inserted at the very outset of the administrative process.

Even if one adopts the position, contrary to the view taken by the APA, that absence of identification with the deciding agency is generally desirable, it must also be borne in mind that in the case of a borrowed examiner this is combined with a presence of identification with another agency. The combination seems surely undesirable, since it assures the loan business a position of secondary importance.

It is of course impossible to measure with any precision the extent to which "invisibility" and "lack of identification" have actually impaired examiner performance on loans. Borrowing agencies and the litigants which appear before them have little basis upon which to make a comparison. Though they may complain, for example, about the length of time which a borrowed examiner takes to render his decision, this complaint is not unheard of in those agencies with their own examiner staffs. And the mediocrity which a particular examiner displays on loan may be no different from the quality of his performance within his own agency. Nevertheless, even making allowances for such imponderables, the interviews conducted in connection with this study indicated that "invisibility" and "lack of identification" have had their adverse effect. For example, according to the account of a staff member of one borrowing agency, in one instance, after more than three months had elapsed since completion of the hearing, the agency's attempts to ascertain when the opinion could be expected were finally rewarded by a letter from the examiner, returning various materials pertinent to the case, "inasmuch as he understood his opinion was no longer required." 94 lt appears that

94. Taking the broad hint, the agency decided the case on the record, without benefit of a recommended decision. Lest the reputation of the current examiner corps be impugned, it should be noted that the examiner in question has since retired. 
shortly after the hearing in the case, the examiner had transferred his permanent position to a new agency which was busy and made heavy demands upon his time. "Invisibility" and "lack of identification" made it inevitable that the borrowed work would be given short shrift-though it is unusual and regrettable that it should have passed on entirely unshriven.

\section{The Need for Restructuring and a Proposal}

Except for that initial failure to exercise the power of selection which resulted in the Long Beach case ${ }^{95}$ the Commission's administration of the loan program seems to have been successful. While the program might be more tightly structured and formalized to give a greater appearance of efficiency, it is really doubtful whether such measures would help, rather than hinder, the attainment of the principal goals. It is initially tempting to suggest, for example, that the Office of Hearing Examiners require monthly reports concerning the workload of the hearing-examiner staffs in the various agencies, thereby enabling it to tell at a glance the availability of examiners for loan work. But in fact, through its regular contacts with the examiners and their Chiefs, the Office knows quite well which staffs are generally busy and which are not. Moreover, the hearing business of the various agencies fluctuates so rapidly from week to week that a workload report would be unreliable almost as soon as it was submitted. This matter, like many others, is better handled by a few phone calls than by reference to a written report. Informality and flexibility of procedure, with the resultingly large scope afforded to the discretion of the Office of Hearing Examiners, is one of the great strengths of the loan program; it should be retained.

There is, however, one major improvement which the Commission should consider. It would be misleading to call it merely a change in the administration of the program, since it would in fact alter the basic structure to a form probably not envisioned by the draftsmen of the APA. Yet the basic purpose of this alteration would in a sense be stability rather than change; modification of structure is necessary in order that, under newly developed conditions, the essential operation and effect of the loan program may remain the same as originally intended.

The newly developed conditions are traceable ultimately to

95. See text accompanying notes $35-43$ supra. 
enormous increase in the demand for examiner loans. As noted above, this demand has recently reached the level of almost 100 per year, as compared with only 9 loans during the entire period from June of 1947 to January of 1954. The increase is the result of a number of factors which are more likely to intensify than to disappear in the foreseeable future-including expansion, both by legislative and by judicial decree, of the categories of hearings which must be conducted under the APA; constant growth in the number of separate "agencies," as that term is defined in the APA:96 and a rise in the sheer volume of federal administrative activity. Of course the number of examiners available for borrowings has increased as well-from approximately 100 in 1947 to approximately 600 at the present time. But in addition to the fact that this rate of increase does not match that in the number of borrowings, it must be borne in mind that one of the efficiencies of scale is maximum continuing use of personnel. An agency with only three examiners may well encounter periods during which one of them has some time to spare; but an agency with enough business to occupy thirty examiners will find that the occasional decrease in one aspect of its operations is likely to be counterbalanced by an increase in some other aspect, so that it can rarely be expected to have ten examiners with time to spare. Moreover, approximately 60 percent of the increase in the examiner corps since 1947-that is, approximately 300 members of the current corps-is accounted for by the Social Security Administration, whose examiners are generally unaccustomed to formal, adversary proceedings of the complexity which may be involved in most loans ${ }^{97}$ and are less accessible for ready borrowing by other agencies because they are scattered in large and small cities throughout the country. Thus, except for the numerous Title VI hearings conducted by their parent Department of Health, Education and Welfare, and for which they have been specially trained, ${ }^{98}$ Social Security examiners are almost never detailed on loan.

From this fact that the demand has outstripped the readily available supply, two results have quite naturally flowed. First, some agencies confronted with a grave but temporary need for examiners

96. 5 U.S.C. $§ 551$ (Supp. V, 1970).

97. Because the Commission has found their work to be less difficult, Social Security examiners are alloted a grade level of GS-15, as compared with GS-16 for all of the major rcgulatory agencies.

98. See text accompanying notes $56-59$ supra. 
have taken steps to insure that borrowed examiners would be available. This has been possible in the case of the constituent agencies of the Department of Health, Education and Welfare, whose central administration has evidently caused one of its constituent agencies, the Social Security Administration, not only never to refuse a loan to another constituent agency for the purpose of holding a Title V1 hearing, but even to devote its examiners' time to training for that very purpose. Thus, although the Social Security Administration has expressed a constant need to increase its examiner staff, ${ }^{99}$ it found itself able to contribute 49 of the 86 examiner loans made in Fiscal 1970-all for Title Vl work, and all except one to other agencies within the Department of Health, Education and Welfare. It is difficult to avoid the conclusion that the Social Security Administration is hiring and retaining some examiner manpower for the very purpose of doing loan work.

The second predictable result of the constant excess of demand over supply has been that some agencies have come to rely upon the demand to provide their examiners with APA work. Of the 37 loans in 1970 not supplied by the Social Security Administration, 17 were supplied from the 11-man staff of the Federal Trade Commission, 4 from the one-man staff of the Small Business Administration, and 4 from the one-man staff of the Civil Service Commission. These figures are not extraordinary but follow a pattern which has emerged in recent years. Those three agencies have accounted for a vastly disproportionate amount of the loan work; correspondingly, a disproportionate amount of all the APA work done by the staffs in those three agencies is work done on loan. It thus appears that the loan business has come to be relied upon both as a means of reimbursement for examiner time which the agency itself cannot use to full effect and also as a means of keeping examiners relatively busy and contented with appropriately challenging work.

It is not suggested that these developments are improper or that they have necessarily been bad in their net effect. To the contrary, it would appear that they alone have enabled the loan program to meet the manpower needs of the agencies. On the other hand, it may well be questioned whether these means are most efficient and most consistent with the purposes of the loan program, and whether they can be relied

99. The Social Security Administration sought to add 39 new examiners to its staff in 1969 and another 50 in 1970. In neither year was it able to fill all the positions. 
upon to endure. The induced hiring or retention of examiners for the very purpose of going on loan has effectively met the need of the Title VI cases solely by reason of the happy circumstance that the agencies which felt the need happened to be part of a department which had power over one agency with a large examiner staff. In the next emergency, that circumstance may not exist. Moreover, it is neither efficient nor in accord with the intent of the loan provision of the APA for an agency charged with the execution of its own substantive functions to intentionally overhire or, alternatively, intentionally divert examiner manpower which it needs itself. The second expedient which has saved the loan program in recent years - the repeated use of examiners who were not intentionally hired for loan work but who have really become superfluous as far as the work of their own agencies is concerned-is even more obviously inefficient and contrary to the intent of the Act. Surely the morale and professionalism of any examiner will suffer from the awareness that he has become something of a spare part within his own agency, however useful he may in fact be to the administrative system as a whole. It is one of the virtues of the loan program that it can prevent the unhappy consequence of a reduction in force when there occurs a sudden and temporary decline in the business of a particular agency. But like all virtues, this one can be carried to a vice, and that has occurred when the loan program enables and assists the maintenance of staffs which are permanently excessive. Indeed, when it has this effect it is achieving the precise opposite of its intended purpose, which was to forestall the hiring of "part-time" examiners, not to facilitate their retention. And if the "intentional overhiring" expedient cannot be relied upon to recur, the "accidental permanent availability" expedient can be relied upon neither to recur nor to continue. The sudden and drastic decline in the workload of the Federal Trade Commission was surprising; repetition of the phenomenon in another agency with a large examiner staff would be miraculous. And the FTC itself, while not cutting back its staff as long as there is loan work for them to do, is allowing the staff to deplete through the normal attrition of transfer and retirement. ${ }^{100}$

In summary, the undoubted success of the above-discussed expedients in enabling the loan program to meet its primary goal

100. The size of the FTC examiner staff has dwindled from a peak of 24 to its current number of only 11 . 
should not obscure these critical facts: that the existing practices are an alteration of the original conception of the loan program; that some such alteration seems necessary if the program is to accomplish its vastly expanded mission; and that the chosen or serendipitously developed alteration is impermanent and in several respects contradictory to the purpose of the APA. These facts suggest the need for consideration of a plan to staff the loan program in the future.

Evidently, the only means of assuring an adequate supply of examiners for loan work is to employ examiners for that very purpose. This might be achieved by persuading a number of agencies to remain permanently overstaffed, and it might be done in such a manner that no single agency would be so seriously overstaffed as to affect examiner morale. But it would be administratively much more efficient, and would in addition serve other desirable ends, to create within a single agency a small corps of "examiners-at-large," charged with the primary responsibility of servicing those agencies without their own examiner staffs. This corps would have its own Chief Hearing Examiner whose specific function would be to see that his staff meets the needs of other agencies in a prompt and efficient manner. It is of course desirable that the agency within which this corps is established be essentially a "service" agency-that is, not one which has a separate mission of its own that might cause its supervision of the loan corps to be given second priority, but rather one whose entire function is to provide for the needs of other agencies. The Administrative Conference meets this qualification, but its structure and outlook are directed toward research and recommendation rather than the active administration which supervision of the loan corps would require. The more obvious choice is the Civil Service Commission, a "service" agency which is specifically concerned with personnel administration. Great advantages of efficiency, moreover, exist in having the corps located within the very agency which must, under the APA, select the examiner for loan. Indeed, it is difficult to imagine the system operating otherwise. It is true that prior to adoption of the APA and since, some have contended that the Commission is not by its nature qualified to supervise quasi-judicial personnel-or, for that matter, legal personnel in general. ${ }^{101}$ But unless the APA's rejection of this

101. The Attorney General's Committee had proposed the creation of an Office of Federal Administrative Procedure which, among its other functions, would have exercised that 
position is reconsidered, it would seem almost essential that any loan corps of the sort here discussed be based in the Commission.

The primary impetus for suggesting consideration of a loan corps is its imminent indispensability to the mere continuation of the loan program. But in addition to assuring the program's survival, it seems likely to improve its quality as well. Many of the disadvantages of the loan program discussed in the preceding section could be eliminated or substantially reduced. There would be less reason to mistrust the quality of the borrowed examiner, since the question which the lending agency will ask itself in order to determine his availability is not "Whom can we spare from our own proper work?" but rather "Who is the best member of our staff for this particular job which is our own proper work?" What has been called the borrowed examiner's "invisibility" would also be reduced, since the reputation which he establishes in his own agency and among his own associates will be based entirely upon the quality and efficiency of his performance on loan. It is probably too much to expect that the borrowed examiner's "lack of identification" with the borrowing agency will be eliminated, although some improvement may be expected from the fact that the same examiners will be returning to the same agencies with greater frequency under the proposed system. Yet even if the borrowed examiners do not develop a personal commitment to the work of the agency to which they are loaned, at least they will not suffer from a commitment to the work of some other agency which may cause them to give their loan work second place. Moreover, a Chief Hearing Examiner would have the positive responsibility of seeing that the loan work is done promptly and well. Finally, and most important, the proposed system would enable the borrowed examiners to become educated in the substance and procedures with which they will have to deal. The entire loan corps could be exposed to brief courses on the work of those agencies which

supervision of hearing examiners ultimately given to the Commission by the APA. See ATT'Y GEN. REP. 46-50. That proposal, as well as one which would have placed supervision of examiners in an Office of Administrative Justice whose Director would be appointed by the Judicial Conference of the United States, were considered and rejected in the deliberations which resulted in the APA. See S. Doc. No. 248, 79th Cong., 2d Sess. $41-42$ (1946), reprinted in APA: Legislative History 371. Since the adoption of the APA, the American Bar Association, or at least the Hearing Examiners Committee of its Section of Administrative Law, has maintained as its "official position . . . that the hearing examiner program be taken from the Commission and lodged in an independent office of administrative procedure." 4 ABA AD. LAW SECTION, ANNUAl ReP. of Comms. 21 (1967) (Hearing Examiners Comm. 1966-67). 
are regular borrowers. So long as such courses are not given when particular litigation is in process or in contemplation, they should not be objectionable even if conducted by the borrowing agencies themselves. Although some might oppose an agency's giving such an "indoctrination" course to its own examiners, the complete separation of the loan corps from the borrowing agency, and the consequent absence of any possibility of undue influence, ought to make such a procedure generally acceptable.

The proposed loan corps will also be of value as an experiment. The suggestion is often heard that all examiners should operate from a common "pool" instead of being employed by the agencies whose disputes come before them. ${ }^{102}$ The loan corps would be a modest step in this direction and would yield some concrete information, which does not now exist, as to the feasibility of the "pool." Even if the use of a "pool" is not desirable for all agencies, it may be that the success of the loan corps would induce some agencies which now have small examiner staffs to eliminate them and to rely upon an increased loan corps instead. The possibilities are intriguing, and it is an experiment which can be conducted without coercion of unwilling agencies and without disruption of current procedures in agencies with their own examiner staffs.

If it is administered with foresight and imagination, the loan corps need not reduce the economic efficiency of the present system, nor deprive ordinary examiners of the professional benefits which they now derive from their loan work. The size of the corps should be held at that level which is necessary to attend to the loan business that cannot be handled in the spare time of those examiners in other agencies who are generally busy with their own work. Thereby, examiner manpower will be utilized to its fullest, and the desirable opportunity for diversification of experience will not be reduced. The loan corps examiners would be assigned insofar as possible to those cases arising within agencies that are regular borrowers, thereby maximizing the benefit of the educational courses suggested above, and enabling the development of a certain expertise. It might eventually be possible even to increase the opportunity for diversification and to provide a currently nonexistent opportunity for day-to-day professional contact among examiners in different

102. Such a suggestion was made by a number of the hearing examiners interviewed. It is by no means a new one, having been considered and rejected by the draftsmen of the APA. See S. REP. No. 752, 79th Cong., Ist Sess. 29 (1945), reprinted in A PA: Legislative History 215. 
agencies by establishing a sort of sabbatical program under which examiners might be assigned from their own agencies to the loan corps for one-year terms. If the loan corps is successful enough to induce some agencies to eliminate their own small staffs, it might well grow to a size which would make such a sabbatical arrangement feasible.

Once it is determined that the loan corps will handle only the "overload" of loan work, prospects for its efficient operation and hopes for its gradual increase in size depend upon nonrecurrence of that permanent overstaffing in other agencies which has been discussed above. This can be prevented, or at least discouraged, and its harmful effect upon the loan corps can be eliminated by the establishment of a Commission policy refusing consent-as it has never heretofore done-to the loan of any examiner other than those in the loan corps beyond a specified number of days per year, and refusing consent to cumulative loans by any single agency other than itself beyond a specified number of man-days per year (varying, of course, with the size of the agency's examiner staff). Viewed properly, such a policy would not create inefficiency but would eliminate the subsidization of inefficiency which now exists-a subsidization which is also undesirable because of its effect upon examiner morale. Those examiners who are affected by a reduction in force as a result of this policy could be added to the loan corps if the caseload warranted; in any event, the number of examiners in all agencies has now reached such a level, and turnover by reason of retirement will soon attain such a regular rate, that transfer of the "riffed" examiner to another agency will be easily arranged. Failing this, his wait for the next available examiner job at his level, to which he is entitled, ${ }^{103}$ will surely not be long.

The optimum time schedule for the adoption of the loan-corps program depends upon whether it is decided to wait for the withering away of the current examiner surplus at FTC and the Small Business Administration or rather to take affirmative steps for its elimination. The latter course is not only feasible but is administratively more convenient, since it would enable the loan corps to begin with seasoned examiners. The examiner at the Small Business Administration and those FTC examiners not needed for disposition of that agency's own business could be transferred to the Commission

103. See note 62 supra. 
and, together with the Commission's present examiner, would comprise the initial loan corps. This action would of course have to be taken in consultation with the agencies involved, but it "seems likely that they would agree. If any added incentive to their cooperation were needed, the Commission could put into effect at once the limitations on frequency of examiner loans suggested above, making the retention of examiners not needed for dispatch of the agencies' own business more costly.

One technical objection to the loan-corps concept merits discussion. The APA required that examiners be appointed "by and for each agency." 104 Although the 1966 recodification of Title 5 eliminated that specific phraseology, ${ }^{105}$ the alteration was specified to be "without substantive change." ${ }^{106}$ Since the word "by" in the original provision already provides an adequate indication that the examiners are to be employees of the agency, it might be thought that the word "for" must fairly be understood as requiring an examiner's appointment to be for the primary purpose of handling the agency's own work, although loans may be permitted once this purpose has been adequately met. On the basis of such an interpretation, it could be argued that the Commission would act improperly in hiring examiners explicitly to do the work of other agencies. This argument might be met by the hair-splitting defense that the Commission's assigned task is, generally speaking, to meet the manpower needs of other agencies, and that, more specifically, section 11 itself makes it the Commission's business to provide manpower for examiner loans. Ultimately, then, the hiring would be "for" the Commission, even in the sense of being for the purpose of handling its own work. But a more basic and honest reply to the argument is that its interpretation of section 11 attributes to the pertinent language a precision and stringency which was not intended. Nothing in the legislative history of the APA indicates any fear that some agencies might choose to use their examiners to do the work of other agencies, or any desire to guard against such improbable munificence. The Bill originally introduced by Senator McCarran ${ }^{107}$ and the Senate Judiciary

104. Act of June 11, 1946, ch. $324, \S 11,60$ Stat. 244 (quoted in the text accompanying note 4 supra).

105. The corresponding text now reads "[e]ach agency shall appoint." 5 U.S.C. § 3105 (Supp. V, 1970).

106. Act of Sept. 6, 1966, Pub. L. No. 89-554, § 7(a), 80 Stat. 631.

107. S. 7, 79th Cong., Ist Sess. (1945). 
Committee Prints of May and June, 1945, which suggested certain amendments to that Bill, provided only that examiners would be appointed "for each agency."108 This language was important and controversial, for it embodied a rejection of those proposals, some of which were contained in House Bills; ${ }^{109}$ which would have removed the examiners from the agencies entirely and assigned them to one form or other of "examiner pool." It represented a determination that each agency should have its own examiners-not that no agency should be able to hire examiners for the purpose of assisting in some other agency's work.

The origin of the "by" portion of the clause appears in the following excerpt from the Senate Judiciary Committee Reprint:

It is urged that the Civil Service System be utilized, as provided [in the proposed text set forth above], with or without certain modifications. The first of these modifications is that examiners be appointed "by each agency" rather than "for each agency. . . ."

This proposal also raised a controversial point. The mere fact that examiners were to be appointed "for" specific agencies did not necessarily require that they be appointed "by" those agencies. The original Senate Bill was not explicit on the point, although since the appointments were to be made "subject to the civil-service . . . laws" they would presumably have been made by the agencies. The lack of precision on the point apparently caused some misgivings, in light of the fact that four of the House Bills under consideration specifically provided for appointment by someone other than the agencies themselves. ${ }^{111}$ Evidently, at the time of the Committee Print those within the Senate Judiciary Committee who shared these misgivings believed that the word "by" would clarify that point, as well as convey the meaning borne in the original version by the word "for." And presumably the "for" advocates believed that the identity of the appointing body was clear enough and that what needed supreme emphasis was the fact that the examiners were to be employed within

108. See APA: Legislative History 41 (discussing the Committee Prints).

109. H.R. 339 and H.R. 1117, 79th Cong., 1st Sess. (1945), reprinted in APA: Legislative History 139, 147.

110. APA: Legislative History 42.

111. H.R. 184 and H.R. 1206 provided that the examiner be nominated by the agency in which he would serve but be appointed by an Office of Federal Administrative Procedure if it found him qualified. Id. at 134, 171. H.R. 339 and H.R. 1117 provided for the appointment of hearing officers by three Commissioners to be named by the President with the advice and consent of the Senate. Id. at 142, 151. 
the agencies themselves. The final result-predictable enough-was the use of both words, a triumph of caution and compromise. In light of this history, neither the use of both words separately nor their use in combination should be understood to contain any prohibition of the proposal made above. 